\title{
A MAN WHO KNEW MEN: THE MEMOIRS OF MAJ M.G. IND
}

Dr S. Monick*

\section{INTRODUCTION}

In January 1990 there occurred the death of Maj Montagu G. Ind, at the age of 89 . He was, to the best of the author's knowledge, the last surviving member of those seconded Royal Navy personnel who sailed to South Africa in the three vessels, Crozier, Eden and Foyle, and who formed the nucleus of the South African Naval Services $(1921-1934)$. However, it is felt that his memoirs possess a deep and multi-faceted appeal, which transcend his long and extremely varied military career (spanning 40 years and encompassing service in the Royal Navy, South African Naval Services, South African Instructional Corps and South African Air Force). This interest may be defined in terms which the author categorizes as both intrinsic and extrinsic. The intrinsic facet relates to the subject of the memoirs, rooted in the personality and service of Maj Ind. It is beyond dispute that that career is truly extraordinary, in several important respects. First, with regard to the biographical dimension, Maj Ind was, in all probability, the youngest member to serve in the ill-starred and horrendous Gallipoli campaign, serving in the Royal Naval Division, renowned for the extremely heavy casualties that this unit incurred, and the savage fighting in which it was involved. Indeed, his extremely youthful experiences in combat have provided the source of the title of these memoirs. As Maj Ind states at one point, his service in the Dardanelles had formed a profound barrier between himself and those of his own age, as he had 'known men' in the extremities of combat, an awareness which, obviously, could not be shared with his peer group. Second, Maj Ind participated in little known, but nevertheless fascinating, episodes in British military history; exemplified in his service with the naval expeditionary force to Russia, immediately following the end of World War I. His ship's sinking of a Russian destroyer, and capture of a second, highlights the revelation of obscure passages in the Royal Navy's history, through the medium of Maj Ind's memoirs; which relate at that point to the British Government's support of the newly independent Baltic states, in the face of Bolshevik aggrandisement.
Third, from the vantage point of the broader context of military history, he was a most notable (if anonymous) pioneer with regard to the South African armed forces, at two highly significant phases of their development, within the specific context of signals, his specialist field. The first was the formation of the South African Naval Services, the immediate ancestor of the modern South African Navy, and the second the instruction of the wartime pilots of the South African Air Force. These aspects may, in all probability, appear far less dramatic and exciting than the first two facets of his service career, discussed above. Nevertheless, they embody vital contributions to the development of the South African military machine, in so far as Maj Ind was instrumental in developing the proficiency of numerous sailors and airmen within the sphere of signals. Indeed, Maj Ind's career in this respect embodies an observation made by Peter $\mathrm{H}$. Liddle, in his book The sailor's war 1914-1918.

'Signalmen, telegraphists, writers, tradesmen like blacksmiths and carpenters, gunners and various types of artificer and stoker were among the special areas of service holding their own promotion ladders through to petty officers and indeed in some cases to warrant officers.'

Maj Ind's service pursued this particular path, his attainment of the rank of Acting Chief Yeoman of Signals, the technical counterpart of Chief Petty Officer, during his secondment to the South African Naval Services, illustrating Liddle's point. Maj Ind's most important contribution to the signals instruction of SAAF personnel, during World War II, embodies the injection of the specialist skills attained in the course of his naval career into the air arm of the Union Defence Forces, as well as with regard to the ancestor of the South African Navy.

There is, however, a distinct and quite separate sphere of interest attaching to Maj Ind's memoirs, which may be classified as extrinsic. This relates to the special process by which the material was compiled. For the following article rep- 
resents, essentially, an exercise in oral history. It is based, in the main, on taped conversations with Maj Ind, which were recorded on 27 November 1987, 7 December 1987, 19 December 1987 and 5 January 1988. These orally transmitted reminiscences form the major part of the material included in this article (supplemented by various notes kindly furnished by Maj Ind, and now contained within the archives of the South African National Museum of Military History). The author strongly feels that oral testimony represents a vital dimension in the study of history. Many who made vital contributions to the fabric of a nation's military history are unrecorded in published sources relating to the events in which they were involved. Oral history represents a means of overcoming such a void, and thereby embodies an essential primary source. Moreover, such testimony graphically captures the tempo and atmosphere of the particular phase of history recorded by the speaker.

It may, justifiably, be argued that the author's interpolations or commentary forms an unduly heavy proportion of the article; possibly introducing an element of imbalance with regard to the relationship between writer and author. In extenuation, the author wishes to state that there are two central reasons for this characteristic. First, Maj Ind refers to institutions and events which may well be unfamiliar to the reader. Examples which immediately spring to mind are: the trench warfare during the Gallipoli campaign; the Royal Naval Division; the naval expedition to the Baltic states during the Russian Civil War of 1918-1921; and the formation of the South African Naval Services in 1921. In order to relate Maj Ind's personalized vantage point to the background in which it is rooted, the author has thought apposite to expand upon the institutions, events, personalities, etc projected from a personal eye-witness viewpoint. The reader, it is hoped, is thus furnished with a more detailed external frame of reference. Second, the juxtaposition of this intervention with the subject's personal reminiscences has been thus structured in order to illustrate the value and significance of oral history. For oral testimony generates a transmission belt, so to speak, or frequency, by which the individual experience points to the larger historical fabric, heightening our awareness of the seminal events in the speaker's record.

It will be noted that, in this process of interaction between author and subject, a strict division between the two has been maintained throughout the article.

The author is indebted to Mr John Nixon, who performed a most essential liaison role in the conversations with Maj Ind, and who furnishes a foreword to the article. S. Monick.

\section{FOREWORD, by J. Nixon.}

The story related in the following text is an account of the life of Maj Montagu G. Ind. This professional sailor, as he can surely claim to have been, was a member of the 'eyes and ears of the fleet', naval parlance for communications and signals. During the very early period of his life, in the course of the First World War, he served with the Royal Naval Division. He enlisted at the age of 14 and shortly afterwards found himself in action at the Dardanelles, for the major part of that abortive campaign, which ended in December 1915. After a short break in his service, brought about by his father arranging his release on the grounds of a misrepresentation concerning his age when Maj Ind attested for service, he then enlisted in the Royal Navy; this time it was with his parents' consent, as they recognized his keenness to serve his country in time of need. But he ranked lowest in the Navy, as 'Boy 2nd Class'. He served with dedication and accelerated progress. He was in the battle cruiser force of the Grand Fleet, serving in HMS Birmingham and HMS Caradoc. He later served in destroyers, and was selected, as a signals specialist, to be a nucleus member of a team to establish the South African Navy. In later years he became a top grade officers' mess caterer in the SA Union Defence Forces and then, during World War II, and after, was Chief Signals Officer in command of 64 Air School (radio and signals), with the rank of Major. After the termination of his military service in 1955, he was employed as Recreation Club Manager/Secretary on a large gold mine on the East Rand.

John Nixon

1989

Please note that explanatory notes in brackets are by the author-signified by SM.

\section{SERVICE IN GALLIPOLI}

In late February, or possibly very early in March 1915, I enlisted in the Royal Naval Volunteer 


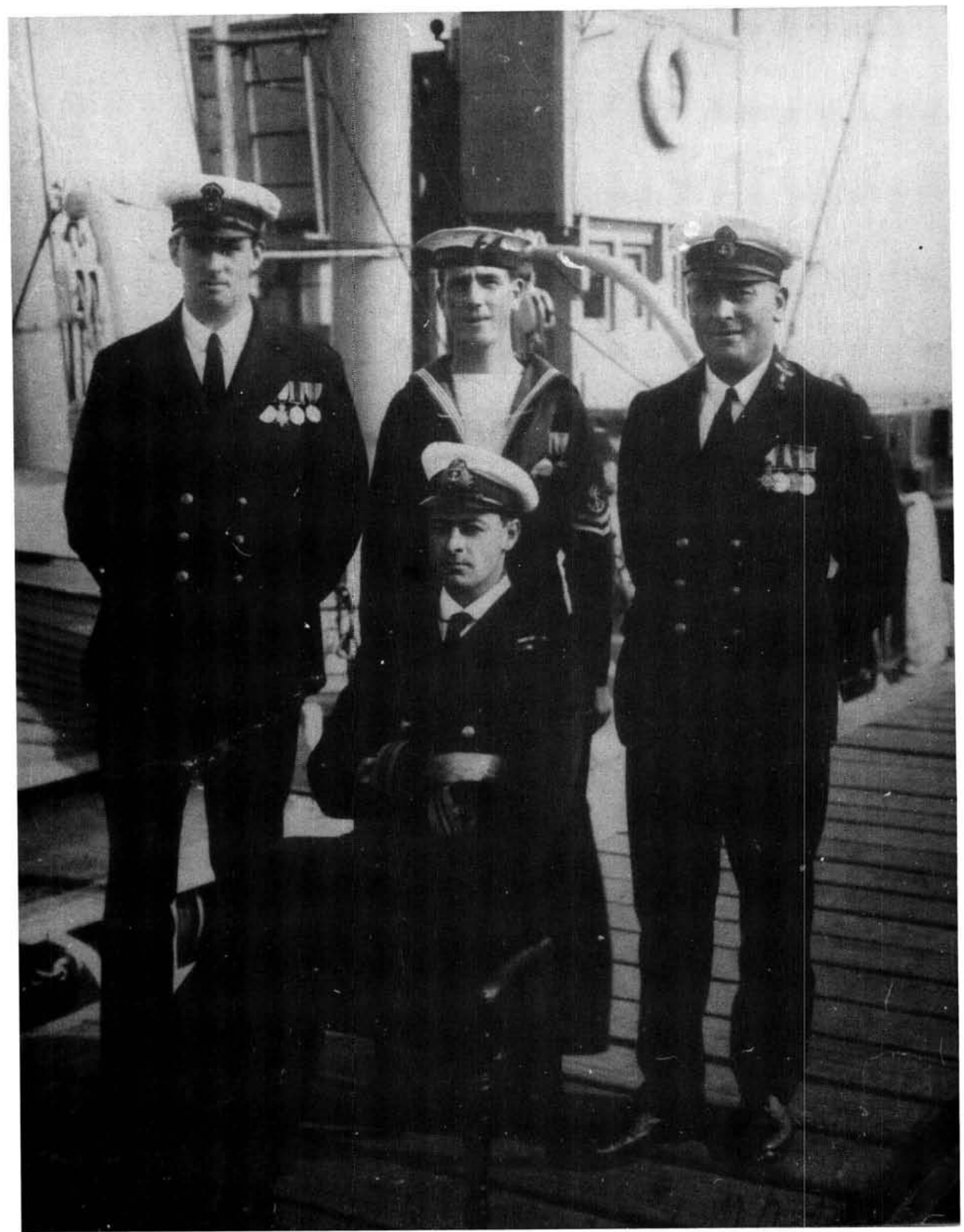

Leading Signalman M.G. Ind. (back row, centre)

This photo was probably taken during the 1920 s (ie during the early phase of his career with the SA Naval Forces), on the basis of the junior rank which he then held. 
Reserve (London Division); having falsified my age by tampering with my birth certificate to create the impression that I was one year older than I actually was. I was in fact 14 years of age at the time (my birth date being 26 October 1900). Why did I join when just a schoolboy? It was an act prompted in the main by patriotism, embodied in the excited response to the poster declaiming, 'England expects that every man this day will do his duty.' I was initially posted to Crystal Palace, which formed the Headquarters of the London Division of the RNVR in wartime. At Crystal Palace we undertook practical training in seamanship. My instructors expressed astonishment at my flare for signals, and I was soon posted to the Signals Division, as an Ordinary Seaman. [The vast glass construction, the Crystal Palace, was first built for the Great Exhibition in 1851, and then dismantled and re-erected at Sydenham in 1854. During World War I it was named HMS Victory /I and organized as a training depot, under the command of Cdre Sir Richard William Bulkeley, RNVR, to receive the thousands of recruits that were offering themselves for service. The survivors of the Royal Naval Division (RND) from Antwerp were reformed and re-organized at the Crystal Palace. The blue uniforms were replaced by khaki. Officers and men with previous sea experience were withdrawn from the Division and drafted to the Fleet or to naval training establishments. This necessarily implied the converse; viz that members of the RNVR lacking sea-going experience were transferred to the RND. Hence Maj Ind's transfer. $\mathrm{SM}$.]

In April 1915 I was embarked at Southampton for the Dardanelles, in a troopship named SS Ascanius, travelling via Port Said and Gilbraltar. I was then a member of the Royal Naval Division.

[The Royal Naval Division had been the brainchild of Winston Churchill, then First Lord of the Admiralty. The Royal Naval Division, formed mainly from the Royal Naval Volunteer Reserve, Royal Naval Reserve and Royal Fleet Reserve, had generated intense antagonism within the Navy as well as in the Army. Capt Richmond, Churchill's own Assistant Director of Naval Operations, described the RND in terms of 'foolery' and 'Winston's tuppeny untrained rabble.' In two major respects the RND differed radically from its 19th Century predecessors - the Naval Brigades. First, it was not drawn exclusively from seamen. The fact that a large proportion of its recruits possessed no sea-going experience is probably the source of the hostility that it gener- ated within the Royal Navy. Second, the RND fell under the control of the Army; the second major respect in which it differed from the naval brigades of the Victorian Navy. The belated despatch of half-trained units of the Naval Division to Antwerp in October 1914 had failed to avert the loss of that city, and had almost resulted in total disaster for the RND. It is apparent, therefore, that Maj Ind had transferred to the Royal Naval Division from the RNVR. He would have possessed the rank of Ordinary Seaman, as the Royal Naval Division retained naval ranks. The RND was commanded, during the Gallipoli campaign, by Maj Gen A. Paris, and comprised the following units:

1st (Naval) Brigade (Brig Gen D. Mercer, RMLI)

- Anson Bn

- Howe Bn

- Hood Bn

- Collingwood Bn

2nd (Naval) Brigade (Cdre O. Blackhouse, RN)

- Hawke Bn

- Nelson Bn

- Drake Bn

- Benbow Bn

3rd (Royal Marines) Brigade (Brig Gen C.N. Trotman, RMLI)

- Deal Bn

- Chatham Bn, RMLI

- Portsmouth Bn, RMLI

- Plymouth Bn, RMLI

Its personnel numbered 10007. (The acronym RMLI refers to Royal Marine Light Infantry. Until 1923, when the Royal Marines were re-organized as a corps, the Royal Marines formed regular regiments; the Royal Marine Artillery (RMA) and Royal Marine Light Infantry (RMLI).) From the Autumn of 1915, and at the time of the evacuation five months later, the 1st Brigade was composed of the Drake, Nelson, Hawke and Hood Battalions; whilst the 2nd Brigade comprised the Howe and Anson Bns and 1st and 2nd Battalions of the Royal Marines. Maj Ind states that he served in A Coy of Nelson Bn (cf below). However, it is feasible that the passage of the years had blurred his memory in this regard. For he distinctly recalls landing on $W$ Beach. The authorities consulted record that a platoon of the Anson $B n$ had been landed as a beach working party, and make no reference to $\mathrm{Nelson} \mathrm{Bn}$ landing on W Beach. It is feasible that Maj Ind first served with Anson $B n$ and was transferred to Nelson $\mathrm{Bn}$ at a later stage in the 


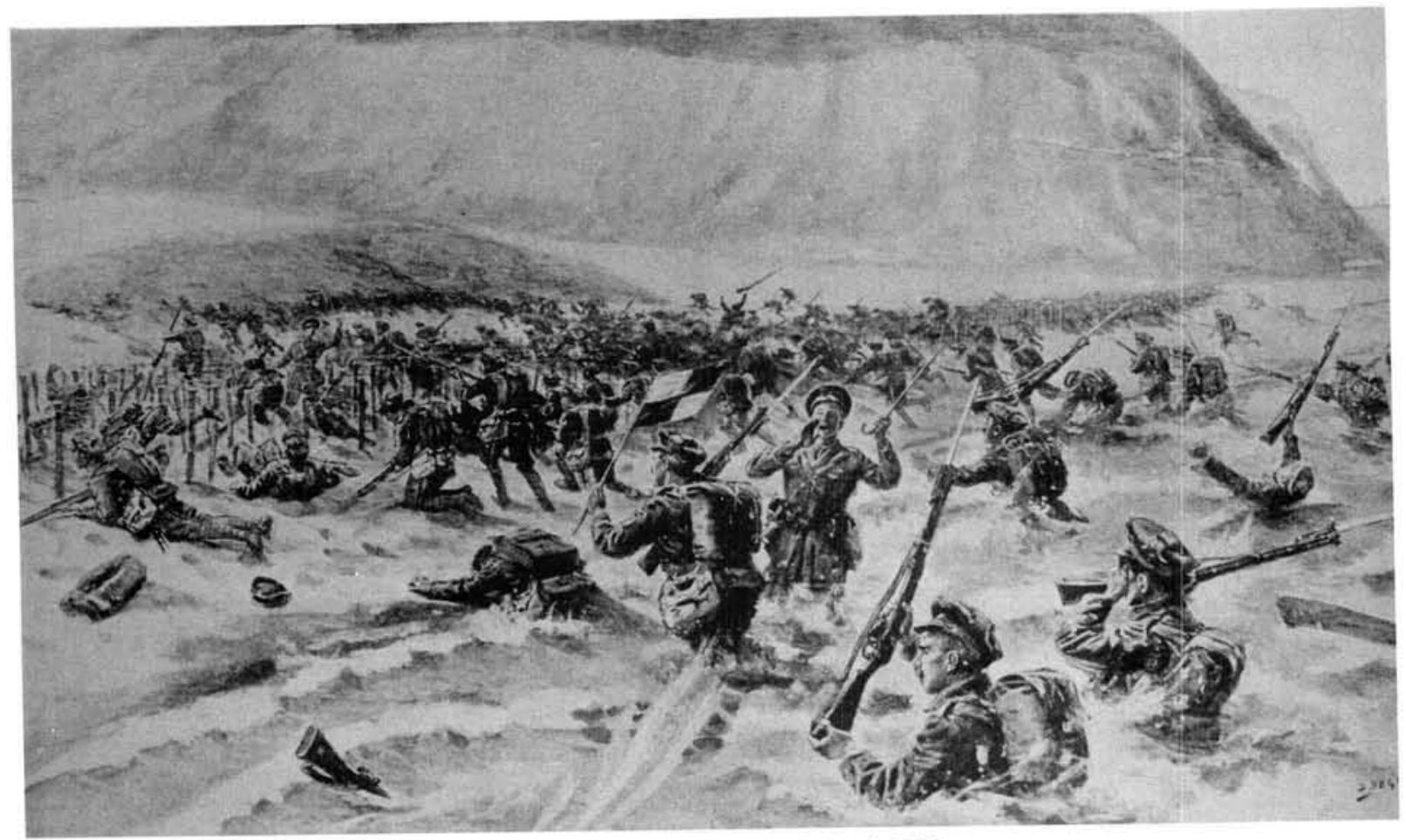

The landing on W Beach, 25 April 1915

campaign. The extensive and drastic re-organization occurring within the RND several months following the initial landings certainly lends credence to this supposition. SM.] I served in A Coy of Nelson Bn [cf above. SM.] We landed at W Beach, at Cape Helles. [This occurred as part of the general landings of 25 April 1915. The other beaches targeted by the invasion force were designated X, V, Y and S Beaches. Lt Gen Sir Ian Hamilton, the commander of the expeditionary force, described W Beach as follows, in his despatch dated 20 May $1915^{2}$.

'W Beach consists of a strip of deep powdery sand 350 yards long and from 15 to 40 yards wide, situated immediately south of Tekke Burnu, where a small gully running down to the sea opens a break in the cliffs. On either flank of the beach the ground rises precipitately; but, in the centre, a number of sand dunes afford a more gradual access to the ridge overlooking the sea. Much time and ingenuity had been employed by the Turks in turning this landing place into a death trap. Close to the water's edge a broad wire entanglement extended the whole length of the shore, and a supplementary barbed network lay concealed under the surface of the sea in the shallows. Land mines and sea mines had been laid. The high ground overlooking the beach was strongly fortified with trenches to which the gully afforded a natural covered approach. A number of machine guns were also cunningly tucked away into holes in the cliff so as to be immune from naval bombardment whilst they were converging their fire upon the wire entanglements.' SM.]

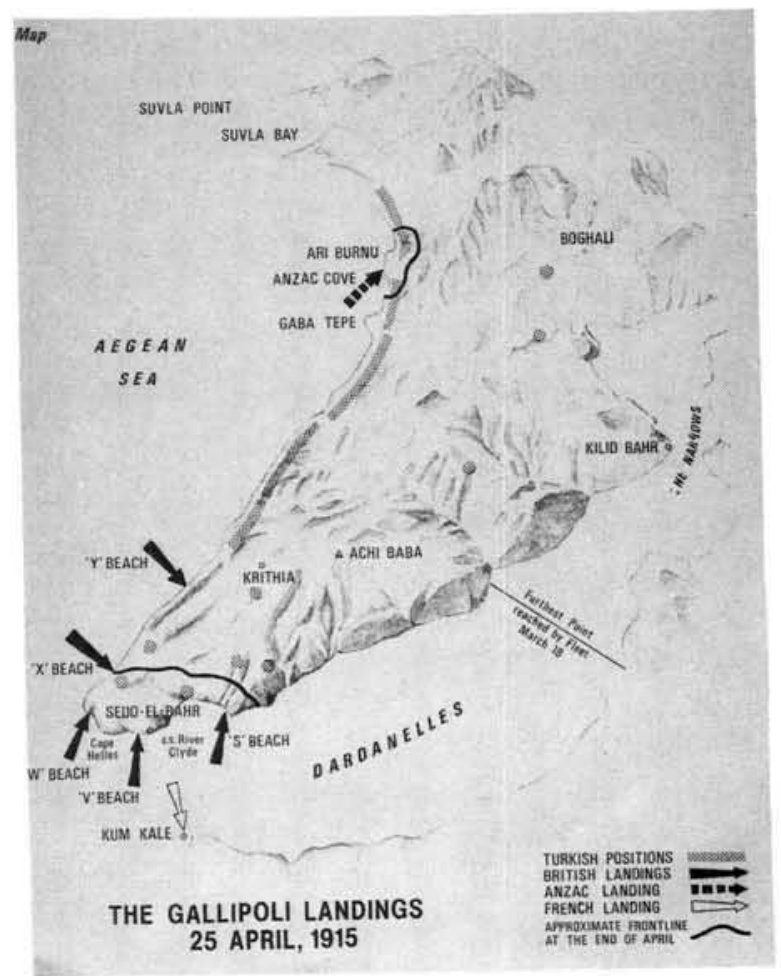

We encountered heavy oppostion as the enemy (the Turks) were in a commanding, virtually im- 
pregnable position on the high banks of the Hellespont. [On W Beach the brunt of the fighting was borne by the Lancashire Fusiliers (who sustained 533 casualties, of whom six officers and 183 men were killed). As was the case with $\checkmark$ Beach, the heavy casualties inflicted emanated from the Turkish forces whom, it was mistakenly assumed, had been annihilated by the naval bombardment. The barbed wire, which had remained intact despite the bombardment, compounded the problems besetting the assaulting force. The Turkish defenders had been severely mauled, but the survivors of the bombardment remained in their trenches. The orders instructed the defenders to permit the attackers to land and advance within $41 \mathrm{~m}$ before opening fire. The Turks realized with satisfaction that the thick wire entanglements at the edge of the beach remained untouched by the barrage. As the first boat load of the attacking force scraped onto the beach the defenders opened fire. The men fell as they sprang from the boats, rifle in hand. Their comrades, who had miraculously escaped the devastating fire, attacked the wire with machetes and cutters; but the wire would not yield. To quote the words of one writer ${ }^{3}$ :

'Caught by hands and arms in the barbs they died spread-eagled on the three-feet coils of rusty farm fencing, their screams heard above the ceaseless fire, their blood pouring down the beach. At one point the wire was breached and a dozen men broke through and tore for the cover of the dunes; and whilst the Turkish defenders concentrated their incessant firing on the fresh boatloads of men arriving - many of whom died in the packed boats without ever setting foot ashore - there were a few other breakthroughs ... But they were mown down as they ran for cover and failed to reach the summit of the beach.'

Reinforcements were off-loaded from the Euryalus and sent in cutters to the beach. Brig Gen Hare, in command of the Helles covering force, managed to lead the survivors of the carnage to a relatively sheltered position under Tekke Burnu. From this position they could return the Turkish fire, which was gradually subdued whilst the boatloads of reinforcements from Euryalus accumulated and consolidated the landing. It is apparent from Maj Ind's following narrative that he did not arrive on the beach in a boat, but waded ashore.

It is considered that the detailed editorial note cited above is justified in terms of the need to accurately reconstruct the intensity and fervour of the combat environment in which Maj Ind found himself whilst wading ashore at W Beach. SM.]

I waded ashore, with full pack, cumbersome uniform, two full bandoliers of ammunition, boots not being of individual fit, a helmet somewhat too large. [This helmet was probably the Wolseley pattern foreign service helmet, of cork, often erroneously described as a pith helmet. SM.] This helmet presented some advantage, as it provided some shade from the sun. In addition I was, of course, carrying my rifle. Uncertain as to what each step forward would rest on, at last I made it. I vividly remember people being hit in the landing.

Our main objective, in the subsequent months, was Achi Baba, a small mountain. [On the Cape Helles front, in the extreme south of the Gallipoli Peninsula, the Allies concentrated their main efforts against the heights of Achi Baba. The efforts to break through the Turkish defences situated on the inland hills barring this objective expressed themselves in the four battles of Krithia, viz:

\section{1st Battle of Krithia (28 April)}

2nd Battle of Krithia (6/8 May)

3rd Battle of Krithia (4/6 June)

4th Battle of Krithia (officially known as the Battle of Achi Baba Nullah) (12/13 July.) SM.]

During the early months of the campaign we effected some slight advances. However, when we were eventually evacuated early in December 1915, some eight months after landing, we were actually slightly to the rear of the positions that we had occupied at the outset. [The efforts to breach the Turkish positions fronting Achi Baba generated the painful and totally futile series of battles of attrition, referred to above. Between the initial landings and the end of July the Allied forces in Gallipoli presented a sick mirror image of the conflict on the Western Front in Europe, manifested by futile attacks upon entrenched Turkish positions followed by enemy counter attacks. The responsibility for the futile frontal assaults which characterized these actions must lie with Maj Gen Sir A.G. Hunter-Weston, the commander of the 29th Division. Lt Gen Sir lan Hamilton saw no future in such costly attacks (in which the Allies were hampered by a most serious deficiency in artillery), but failed to impress his views upon Hunter-Weston and the latter's staff. 
By the end of July the Allies had gained (very approximately) $457 \mathrm{~m}$ in ground, in return for 17000 casualties. (This represented the furthest Allied advance on this front). Maj Ind certainly understates the intensity and ferocity of the fighting in which he was engaged. The RND suffered extremely heavy casualties on 4 June, at the 3rd Battle of Krithia. Hunter-Weston deployed 8 Corps (consisting of the remnants of 29 Division), the Sikhs and Gurkhas of Maj Gen Cox's Indian Brigade, the 42nd (East Lancashire) Division (Territorials), and the RND on the left and centre of his line. The French and their colonials (in strength two divisions) were, as usual, on the right. Their advance preceded by a tremendous bombardment of the Turkish trenches, the RND (Anson, Howe and Hood Bns) succeeded in occupying the enemy front line. At $12 \mathrm{~h} 15$, as if on parade, the Collingwood $\mathrm{Bn}$ moved forward in a long extended line. This battalion had landed on the Peninsula on 30 May, and they marched into the murderous fire of a trench work known as the Haricot Redoubt. The attacks on the left of the Turkish line, executed by the Manchester Brigade of 8 Corps and Indian Brigade, made good progress; to the extent that, after five minutes, the Manchesters were lying on the slopes of Achi Baba, with nothing between them and the coveted summit, awaiting only the word to advance. But they never received this order. For, on the extreme right of the Allied line, by the Kereves Dere, the works that the French had captured proved to be a death trap. They were simply blasted out of them by high explosive and, subjected to an overwhelming counter-attack, were forced back to their starting point. The RND, with its right now exposed by the French retirement, were cruelly enfiladed.

As a result, the trenches that they had captured in the first attack proved untenable. In the subsequent retirement more heavy casualties were incurred. Indeed, the Collingwood Battalion ceased to exist. Total RND casualties in the battle amounted to 1170 , including 40 officers. In the July battles the RND suffered casualties of 79 officers and over 2000 men, and was reduced to 29 officers and 5058 men. Winston Churchill, in a letter to his brother Jack, who was Camp Commandant, GHQ Staff at Gallipoli, wrote of the RND in the following terms:

'Poor Naval Division. Alas the slaughter has been cruel.'

The total casualties suffered by the RND amounted to 133 officers and 1313 other ranks killed, and a further 199 officers and 4838 other ranks wounded. SM.] I remember, in the trench fighting, that a man on one side of me was shot dead and on the other side a man wounded.

I vividly recall that the shortage of water was a major problem. [Water was severely rationed, every drop having to be carried to the front lines. SM.] The water was contained in paraffin tins and conveyed to the front lines by Greek water carriers - the poorest of the poor - and when these containers reached us they were always only one-half or one-quarter full, and invariably leaking. We also relied heavily on mules for the transport of supplies.

[One author graphically recounts the hideous character of the Gallipoli environment at the height of summer"

'By now the heat was becoming almost unbearable. The trenches were like ovens; the grass had long since withered and vanished, and the hot wind stirred up the dust, which drifted across the peninsula, covering everything, and horribly pungent with the stench of war and death. On the limpid sea the corpses of horses and mules floated stiffly. The Navy towed them out and tried to puncture them with bayonets; if that failed the corpses were churned up in the propellers; if they still refused to sink they were left to their own devices, and the hideously mangled carcasses found their way back to the beaches.'

A Cpl Riley wrote of the Helles sector that it 'looked like a midden and smelled like an open cemetery. ${ }^{5}$ ' SM.]

On 8 December 1915 I was evacuated from the Dardanelles, as I was suffering from dysentery. I felt, quite simply, that I wanted to die. [Not surprisingly, dysentery became endemic throughout the expeditionary force in July. The flies swarmed over the corpses and latrines, thenceforth alighting on the men's food. One authority states $^{6}$ :

'Ashore the bloated loathsome green flies "corpse flies" the men called them - were becoming literally pestilential. Feasting on the corpses in No Man's Land, swarming hideously over the latrines, filling every trench and dug-out and covering the food, they were directly responsible for a virulent form of dysenteric diarrhoea - generally known as "The Gallipoli Trots" or "The Gallipoli Gallop" - 
which spread rapidly throughout the Army in July.' SM.]

No further advances were made on the Helles front after 15 July. The ANZACs (Australian and New Zealand Army Corps) never broke out of their bridgehead to the north of the Peninsula, while the Turks looked down from the mountain peaks upon the intruders. Despite reinforcements in July and August (the latter landed at Suvla Bay), no further material gains were made. SM.]

\section{DISCHARGED FROM THE SERVICE}

I left the Gallipoli Peninsula in a small tramp steamer, named the Ermine, of Glasgow, and journeyed to the island of Mudros. There I was admitted to a field hospital, established by the 3rd Australian Field Coy. I never returned to the Dardanelles, as the final evacuation was then in progress. [The final evacuation occurred on 9 January 1916. SM.] I was at the field hospital for a very short time, and then returned to England, as a patient on the hospital ship Aquitania. Upon arriving home, I was sent to the Royal Naval Hospital at Portsmouth, where I made a rapid recovery after several weeks. Regrettably, however, I still have recurrent attacks of this affliction, after some 75 years.

Shortly after my discharge from hospital, I received notification that I had been awarded the 1914-15 Star, at the age of only 15 years. I distinctly recall the great sense of pride that I experienced upon receiving this news. This sense of pride was further enhanced when, shortly after having been discharged [cf below. SM.]. I received a letter of special commendation from the King (signed by his Private Secretary, Lord Stamfordham), expressing appreciation for my patriotism and dedication.

After a period of leave I was despatched to a naval base, Blandford, in Dorsetshire. There । was posted to the Signals Division. I anticipated that, in accordance with the subsequent role of the RND in World War I, my next posting would undoubtedly be the Western Front. However, one day I was informed by the RSM that the Commandant of the camp (who was a Colonel in the Royal Marines) wished to see me. The Colonel informed me that I would shortly be leaving the service. I immediately felt that my father had played a role in my discharge. A rapid surveillance of the office revealed a person partially concealed behind a potted plant and, indeed, it proved to be my father, with whom I returned home in the early months of 1916 . He had played a major role in in securing my discharge from the Navy. He procured a position for me at the Arsenal in Enfield. The work in which I was engaged consisted of book-keeping and accountancy, in which field I possessed a marked flair. However, I felt extremely restless, discontented and dissatisfied. My experiences in the Dardanelles had permanently separated me from those of my own age who, by virtue of their years, had never experienced active service.

\section{SERVICE WITH THE ROYAL NAVY IN WORLD WAR I}

So, at the age of $15 \frac{1}{2}$, I joined the Navy a second time. On this occasion I attested for service with the rank of 'Boy 2nd Class.' [At this time, boys could be inducted into the Royal Navy from the age of 12 years, thence to be trained as apprentice seamen. The boy and his father signed papers to the effect that the former voluntarily bound himself as an apprentice to the commander of the training ship and to his successors, until the age of 18 years had been reached. Thus, being below the age of 18, Maj Ind would have been classified as a 'Boy' entrant. Curiously, however, Maj Ind had qualified as an Able Seaman by virtue of his service with the Naval Division at Gallipoli. Presumably, as the RND had fallen under the control of the Army (cf above), this rank would not have been retained upon his enlistment in the Royal Navy. However, it is apparent that his previous experience obviated any necessity for service in a training ship. SM.]

The very first sea-going ship in which I served was HMS Birmingham, joining its compliment (sailors dislike the word 'crew') on 2 August 1916. Birmingham was a light cruiser. [The Birmingham, commissioned in May 1913, was one of two light cruisers in the Chatham class (the other ship being the Lowestoft). Possessing a compliment of 433 , its armament comprised nine 6 inch guns, one 3 inch anti- aircraft gun, four $3 \mathrm{pr}$ guns, 2 machine guns and 2 torpedo tubes. SM.]

I served in this ship a very short time, and was then posted to the Caradoc, a modern oil-burning light cruiser, serving as one of five ships in No 6 Light Cruiser Squadron. I served in the signals section. [The Caradoc, whose compli- 


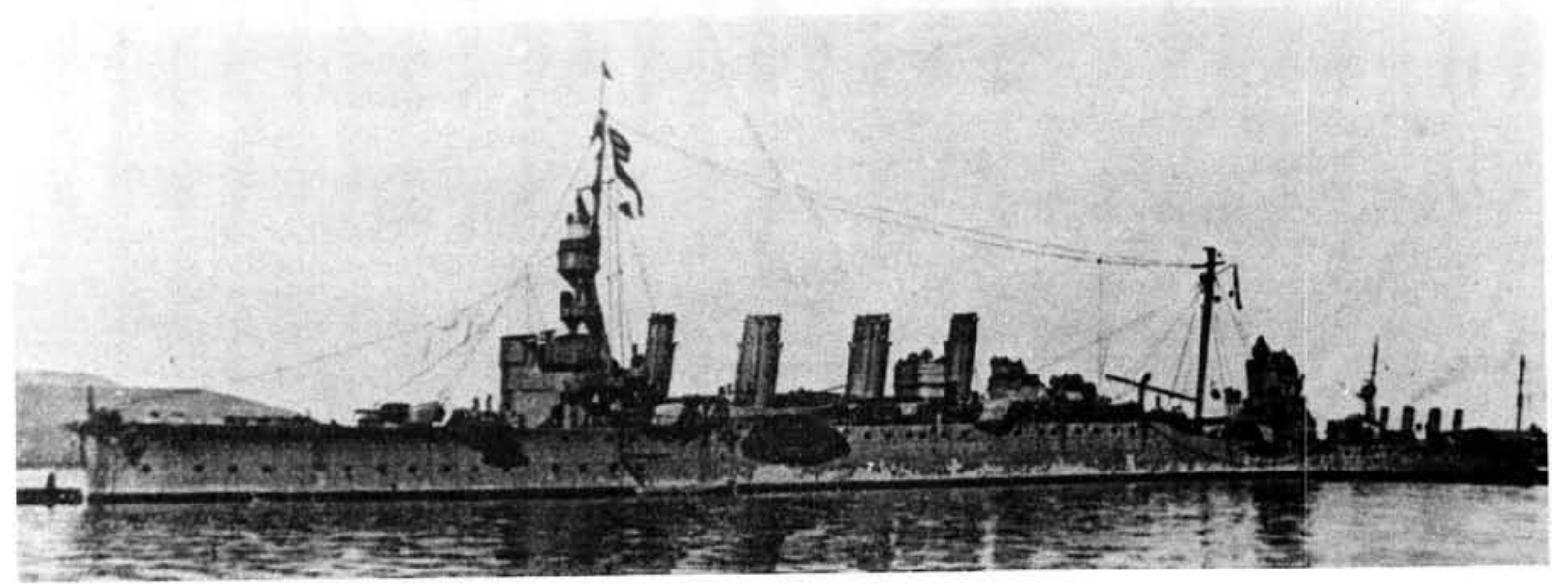

HMS Birmingham.

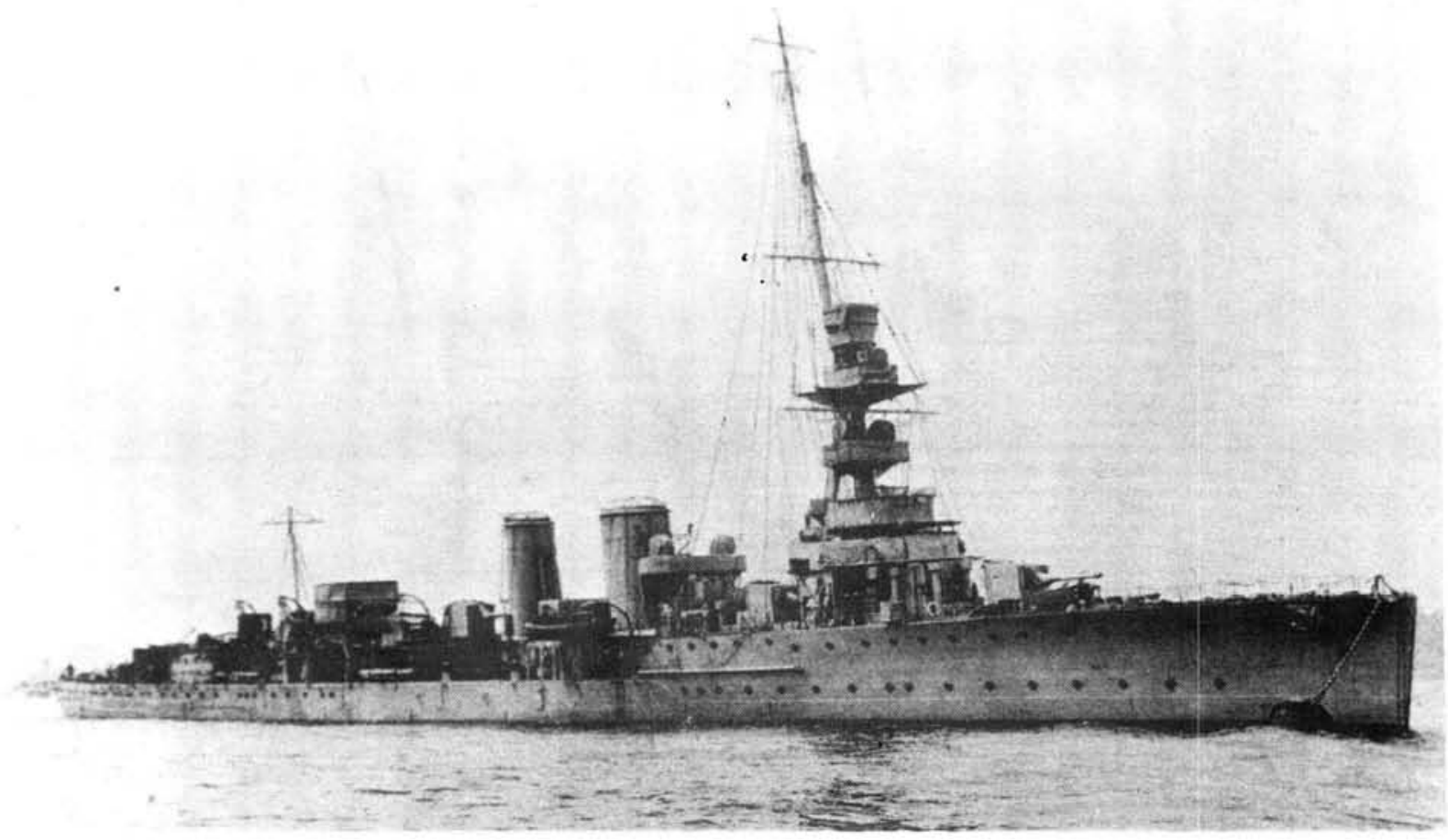

The Calypso

A ship within 6 Light Cruiser Squadron, it was vertually identical to the Caradoc in which Maj Ind served. 
ment numbered 344 , had been commissioned in on 23 December 1916, and it would appear, therefore, that Maj Ind joined this ship in early 1917. He was, in all probability, a member of the light cruiser's very first compliment. She was one of three ships in the Caledon class (the others being the Caledon and Calypso). She was armed with five 6 inch guns, aligned in the centre [two 3 inch anti-aircraft guns, four $3 \mathrm{pr}$ guns, one machine gun and eight torpedo tubes. SM.] I served in this ship throughout the remainder of the Great War and for several years thereafter.

The Caradoc was commanded by Capt William Spencer Levenson-Gower, DSO [1880-1953. This officer was, at that time, the 3rd Earl of Granville. He achieved a most distinguished career in the Royal Navy, ending his career as Vice Admiral W.S. Levenson-Gower, KG, KCVO, CB, DSO. He succeeded as the 4th Earl of Granville. During the period 1924-1927 he served as Chief of Staff and Maintenance Captain of the Nore; as Rear Admiral commanding the coast of Scotland (1931-1933); Lt Governor of the Isle of Man (1937-1945) and Governor of Northern Ireland (1945-1952). SM.]

On 17 November 1917 I was involved, as a member of the Caradoc's compliment, in the second battle of the Heliogoland Bight. [There was a very real possibility, in November 1917 , that a major confrontation might develop between the British and German Grand Fleets, as a result of the British operations which were designed to decisively frustrate German protection of her mine-sweeping in the heavily mined waters of the Heliogoland Bight. Admiral von Reuter of the 2nd Scouting Group assembled a force of mine-sweepers that was to sweep to the north-westwards. The object of the operation, termed a Stichfahrt (or 'thrust voyage') was to fix the position of any minefield that had been lain across the track of the sweepers, and to discover and mark a track around it into clear water. Such Stichfahrten were executed whenever the weather permitted and effected by an organized procession of sweepers and supporting craft. At the head of the sweeping line were the minesweepers and their sweeps, followed by the destroyers with indicator nets, and behind these the 'barrier breakers' (i.e. trawlers especially constructed to absorb the explosion of mines; their holds being filled with wood, cork and cement), with light cruisers and an airship escort. The German forces were - as observed by the British - composed of three groups. The most northerly were composed of minesweepers and destroyers; the central group of submarines; whilst to the south were three or four light cruisers. In addition to the 6th Light Cruiser Squadron (screened by the destroyers Valentine, Vimiera, Vanquisher and Vehement) the British naval forces consisted of: 1st Light Cruiser Squadron, comprising the Caledon, Galatea, Royalist and Inconstant (the screening destroyers being Vendetta and Medway); the 1st Battle Cruiser Squadron, composed of the Lion (the flagship), Princess Royal, Tiger, New Zealand and Repulse (the screening destroyers being: Champion, Verdun, Telemachus, Oriana, Nepean, Obdurate, Tristram, Petard and Tower); and the 1st Battle Squadron, consisting of the Revenge, Royal Oak, Resolution, Emperor of India, Benhow and Canada (the screening destroyers being Noble, Nonsuch, Napier, Penn, Paladin, Saumarez, Valhalla, Prince, Mischief, Munster and Narbrough). (It was customary for cruisers to be escorted, on either flank, by destroyers, who would guard against both submarines and heavier ships). The German laid effective smoke screens, thus impeding the British pursuit and allowing the latter to escape destruction. Shelling, causing damage to both sides, was exchanged. The Cardiff (the flagship of 6 Light Cruiser Squadron) was struck several times, as was the Caradoc, but the latter sustained no casualties. (The other ships in the squadron were the Ceres, Calypso and Cassandra). This inconclusive action represented the very last engagement of the opposing battle squadrons in World War I. SM.]

Immediately following this encounter, a new system of patrolling the North Sea was put into effect. Instead of patrolling in squadrons, the Admiralty decided that single ships would patrol an area which would be immediately adjacent on three sides to another ship engaged in this patrolling. The object was to introduce greater economy and thoroughness in patrolling.

I vividly remember being punished. At the time we were situated at the furthest extent of the North Sea, virtually touching Greenland. I had caught cold and was relieved of duty for three days. This involved an additional half-an-hour's sleep in the morning (this privilege popularly being known as 'garden steerage'.) On the fourth day I slept an additional half-hour. That was my undoing. I was rudely awakened by the ship's policeman (commonly called the 'crusher) and he took me before the ship's captain, who 
delivered a fatherly lecture. [The term'ship's policeman' probably refers to the Master-atArms, who was then in overall charge of discipline on board ship. SM.] I was appalled when I later heard the punishment that he recommended; nine cuts with the cane. This is a reflection of the extremely harsh discipline then prevailing. The cane in question was of the prison, and not the school, variety, and drew blood. The code in the boys' mess prescribed that, should one cry out during this punishment, the victim received a further flogging upon his return. I stuck my silk in my mouth so that I did not cry out. The cuts were not delivered by one sailor, but by two, so that no strength was lost by either in delivering the beating. [Corporal punishment was regularly meted out to boy seamen at this time. Writing of this aspect of the Royal Navy's discipline at this time, Peter Liddle writes ${ }^{7}$ :

'The "stonicky", a heavy short stick wielded by powerful petty officers, discouraged any slackness. "Captain's floggings" were ... quite common. The victim was held pick-aback on a doubled-up petty officer. A senior boy held the offender's head into the neck of the petty officer and four others held his arms and legs stiffly outward. The beatings of six, twelve and, on one exceptional occasion, twenty-four strokes [according to the unpublished memoirs of Capt $\mathrm{H}$ Watson, who was a boy entrant serving in the training ship Indefatigable] were administered with a length of tarred hemp ratline. Tradition decreed that the count was marked by the victim himself shouting out the strokes as they fell on his bottom... Watson ... also wrote of the death of a boy after a less formal beating by one of the petty officers...' SM.]

I also remember being wrecked. We became wedged between the rocks in very dense fog. Although the sea is invariably calm in fog, it was nevertheless a very dangerous situation. Nevertheless, we escaped under our own volition. We were based at Rosyth (located in the Firth of Forth). This was one of the two most important bases; the other being Scapa Flow. Rosyth was the Headquarters of the Battle Cruiser force, whilst Scapa Flow served as the main base of the battleship and destroyer screens. In 1918 a strange incident occurred. A stream of signals was being hoisted from the Cardiff, each one of which was being read by ourselves. One such signal read 'Race steam for full speed and report when ready to proceed'. We slipped our moorings, Cardiff in the lead, and proceeded in line ahead. At the entrance to the River Forth is an island called 'May Island' (popularly referred to as 'The Sentinel') and we knew that if we turned right at this point we would be proceeding towards enemy bases. To my surprise we did in fact turn in this direction and continued on a southerly course. We went to action stations and recognition signals were hoisted. After reaching May Island we changed our formation to line abreast. The look-out on the Cardiff reported 'speck on horizon'. The Cardiff signallers used a 10 inch signalling lamp to challenge this ship, which proved to be an armed cruiser, the latter replying with the correct challenge. When this ship was a reasonable distance in front of us, we made an 180 degree turn, so that we were behind her. We then accompanied the cruiser on a return course to May Island. We did not proceed up river, and the cruiser entered a sheltered bay. The C-in-C (Admiral Beatty), despatched a destroyer (HMS Oak), attached for duty with the flagship (HMS Queen Elizabeth) to pick up a passenger from the cruiser, convey him to the flagship, and then return him. The cruiser reported its regret at not being at the correct rendezvous, due to inferior coal and low morale.

[The passenger was Admiral Meurer, who had arrived on the Konigsberg to discuss peace terms. The date was 15 November 1918. The scene on Queen Elizabeth is furnished by Rear Admiral WS Chalmers, in his book. The life and letters of David, Earl Beatty ${ }^{3}$ :

'When the Koningsberg duly arrived on the evening of the 15th November, Admiral Meurer signalled that the "Sailors and Workmen's Delegates" on board insisted on accompanying him to the Queen Elizabeth for negotiations. Beatty promptly replied that he would only meet an officer of flag rank, and that no one but the Admiral and his staff were to leave the ship. Meurer later thanked Beatty for this courtesy, stating that it was the first time for some weeks that his rank had been recognized!

The German admiral and his staff arrived on board the Queen Elizabeth at 7.30 p.m. on 15th November, and were formally received in silence by Rear-Admiral Brand and Captain Chatfield, wearing swords. It was dark, and a strong electric light was focused on the gangway, behind which Sir John Lavery, the official artist, did a rapid sketch of the scene. This method of securing a pictorial record of such a historic event was chosen in preference to 


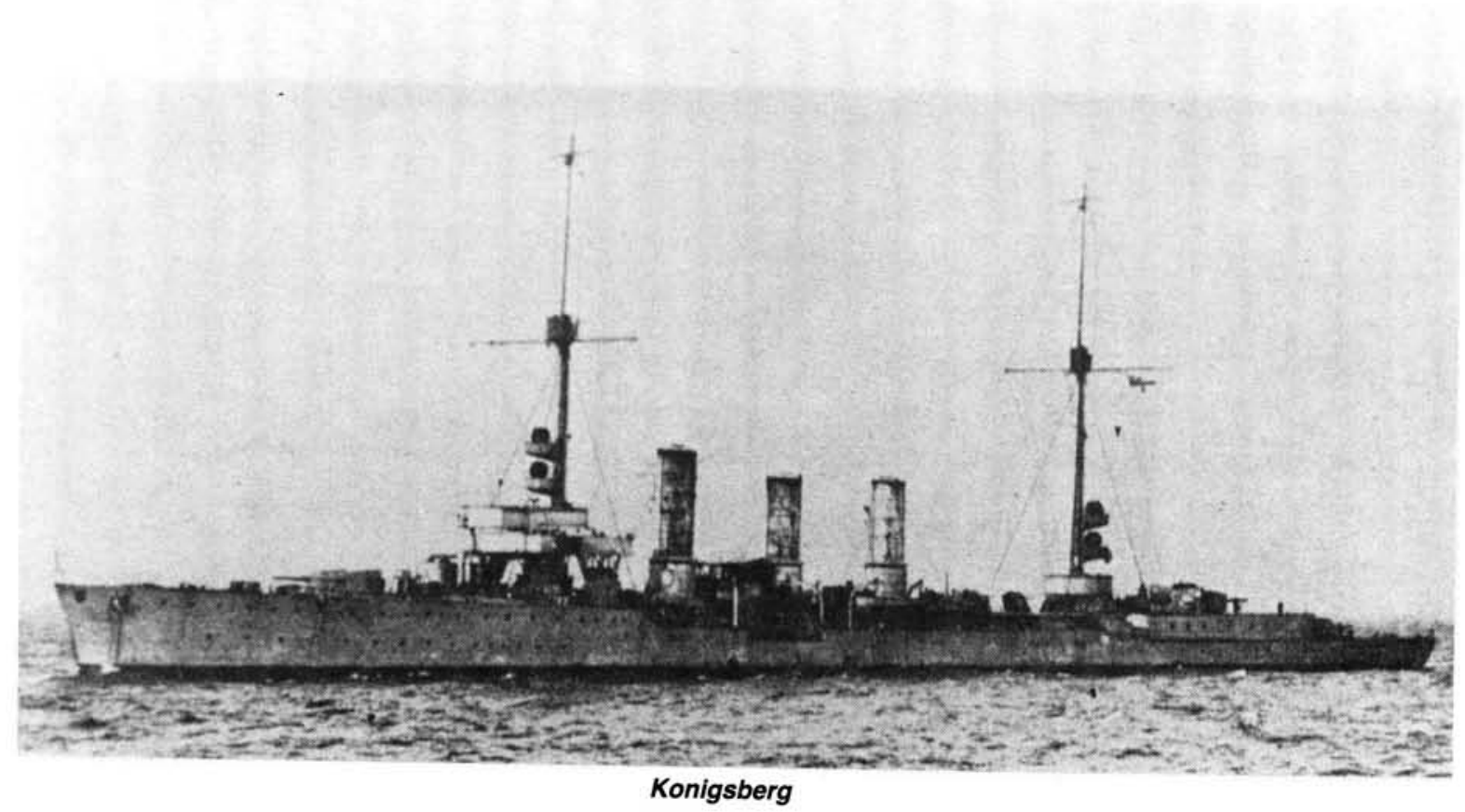

the more modern and brazen one of subjecting the victim to the fire of flashlight photography. Among the British officers present, there was a feeling of some sympathy for Meurer, who, apart from suffering in his flagship the gross indignity of being under the supervision of a Communist mob, was about to negotiate the surrender of the fleet he loved so well.

After exchanging salutes, Brand led the German officers down the companion ladder to the Admiral's dining cabin, where Beatty was seated at the table, with Madden, his Secondin-Command, on his right, and Brock, his Chief-of-Staff, on his left. Also present were: Rear Admiral the Hon Hubert Brand, Capt Ernl Chatfield, Paymaster-Commander FT Spickernell, Cdr RM Bellairs and Cdr WT Bagot (interpreter). At certain stages Vice Admiral Sir M Browning and Rear Admiral Sir Reginal Tyrwhitt also attended. Immediately behind Beatty hung an old naval print of $\mathrm{Nel}$ son, and in the centre of the table, before him, was a bronze lion, a sharp reminder to the Germans that British naval traditions are hard to break. As Meurer stood facing Beatty, the proceedings were opened thus:

Beatty: 'Who are you?'

Meurer: 'Rear-Admiral Hugo Meurer'.

Beatty: 'Have you been sent by Admiral von Hipper as his plenipotentiary to arrange the details for carrying out the terms of the armistice which refer to the surrender of the German fleet?'

Meurer: 'Yes'.

Beatty: 'Where are your credentials? Pray be seated.'

After the credentials had been examined, Beatty handed to Meurer a paper printed in two parallel columns. On the left were the armistice conditions, and on the right the arrangements with which Meurer was expected to comply. Meurer replied that he could not immediately answer all the questions put to him, and requested permission to communicate at once with his High Command. This was granted, and Meurer left the flagship.'

Beatty provides a personalized account of the incident in a letter dated 26 November $1918^{\circ}$ :

'He,[ i.e. Admiral Meurer SM] arrived at 7 p.m. in pitch dark, aided by a thick fog, in which he could see nothing and had no idea he was surrounded by the greatest fleet in the world, [his immediate escort being, of course, 6 Light Cruiser Squadron, of which Ind's ship, the Caradoc, was a member SM]. I arranged a most beautiful setting. My dramatic sense was highly developed at the moment. When he marched up the gangway he was met with a blaze of light from groups of the strongest electric sunlights which lighted the gangway 


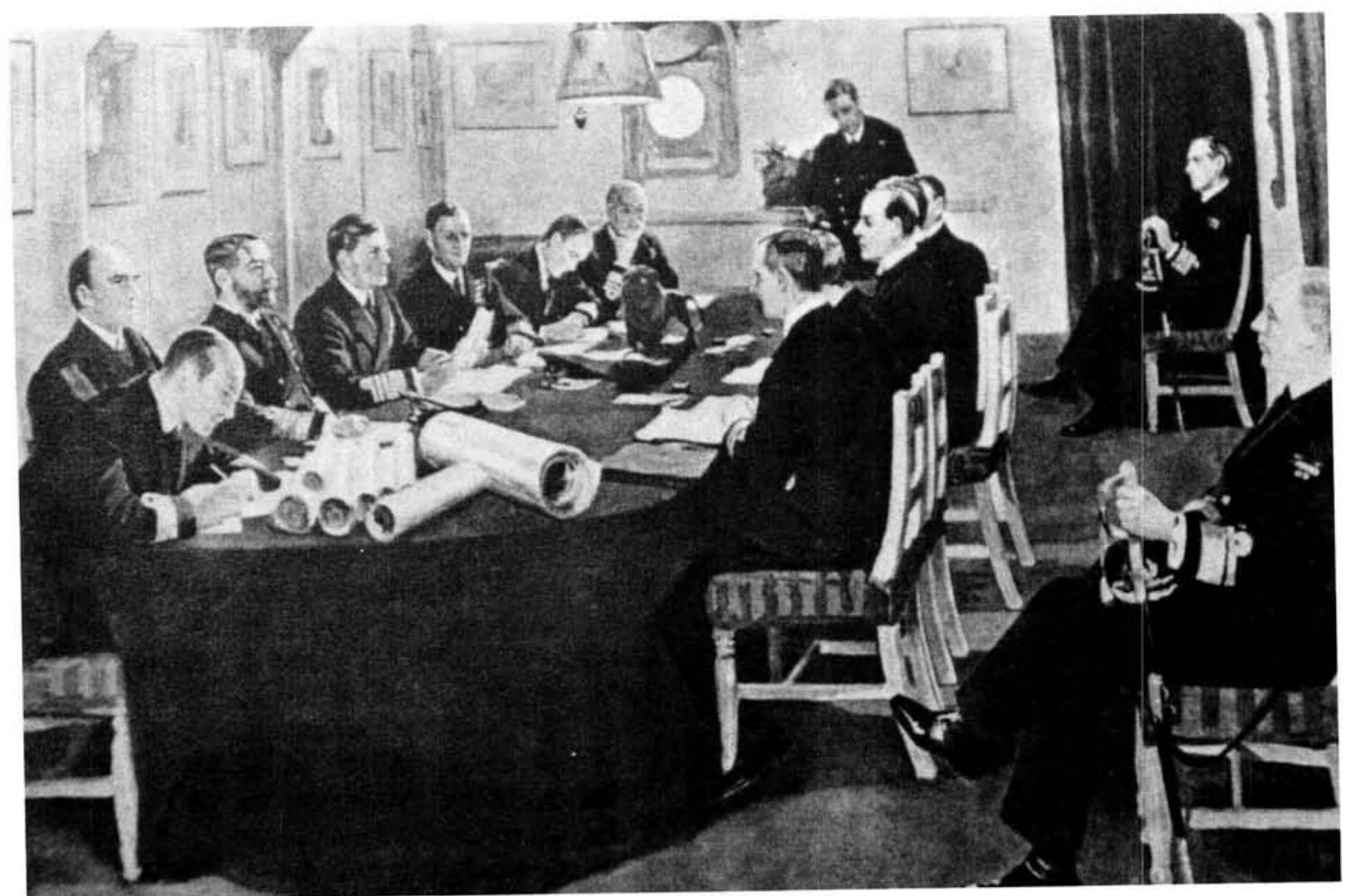

The surrender of the German Fleet, Admiral Beatty reading out the terms. Fore Cabin HMS Queen Elizabeth, Rosyth, November 16, 1918.

Painted by Sir John Lavery

Note: There is a certain degree of discordance between Maj Ind's account and the date on which the surrender terms were read. Maj Ind implies that the Caradoc met the Konigsberg in the period before the Armistice, yet the German cruiser met the Queen Elizabeth on 15 November.

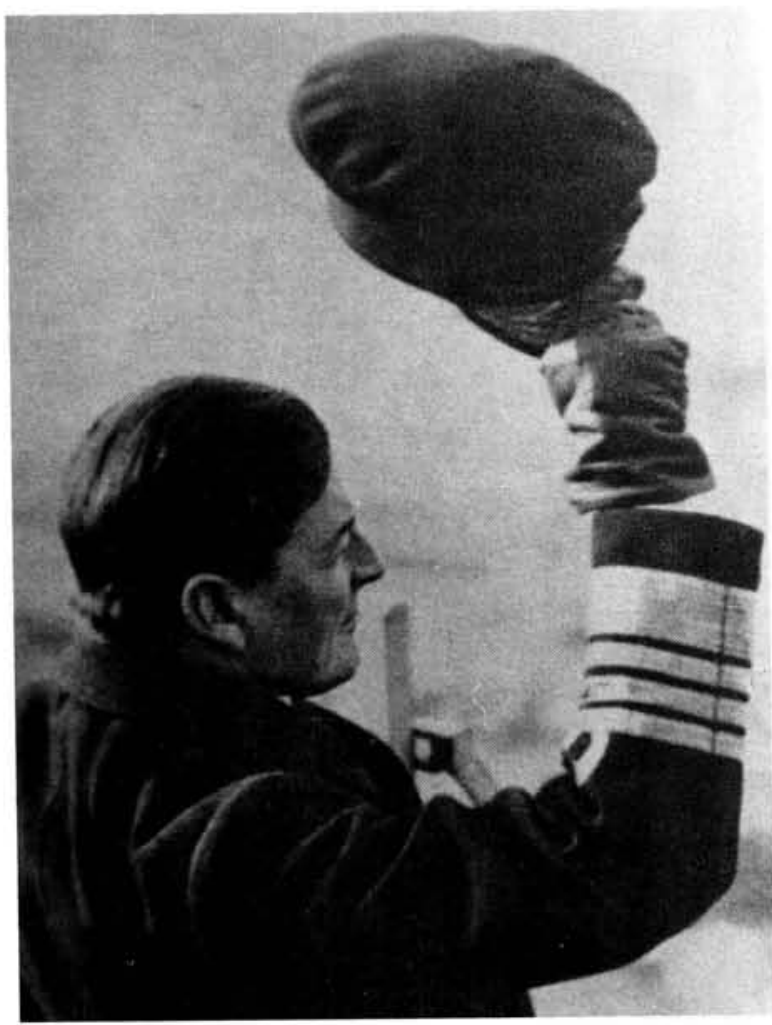

Admiral Beatty acknowledging the cheers of the fleet on the day of surrender. and the path to be trod from there to my hatchway. Outside the path everything was inky black and perfect stillness. Actually, on the edge of the Path of Light, half in, half out, was a line of the fattest marine sentries about two paces apart with fixed bayonets, upon which the light gleamed. Wherever he looked he met a bayonet. He was met by Tommy Brand and Chatfield, who were frigidity itself. The wretch nearly collapsed on the quarterdeck, and his party were led to my cabin, where I met him supported by my Second-inCommand, ... Osmond de Brock, Tyrwhitt, and several members of my staff. I wouldn't accept him as being what he said he was, until he produced documentary evidence in support of his statement and identified his Staff. Having "Pray be seated", I read him my prepared instructions and refused to discuss them, but said they must be thought over and answered on the morrow. They were greatly depressed, overwhelmingly so, and I kept on feeling sorry for them, but kept going by repeating to myself: Lusitania, Belgian atrocities, British prisoners, and I won in a trot. So much so that Meurer, in a voice like lead, with 
an ashen grey face, said: "I must think the Commander-in-Chief is aware of the conditions in Germany", and then in dull, low weary tones began to retail the effect of the Blockade. It had brought Revolution in the North which had spread to the South and then to East and finally to the West, that anarchy was rampant, the seed was sown. It remained for the harvest of human lives to be reaped in the interior of Germany as well as on the frontiers. Men, women and children were dying of starvation and dropping in the streets and died where they lay. Children under six were nonexistent, that Germany was destroyed utterly, the latter with a wail to his tone. It had no effect. I only said to myself: Thank God for the British Navy. This is your work. Without it no victory on land would have availed or been possible. I told them to return with their answers in the morning. He then informed me he had three delegates of the Sailors' and Workers' Council outside who were anxious to take part in the conversations. I naturally said I knew them not, and did not intend to know them better, which was the one source of relief in the stricken party. And they stepped out into the darkness and fog to do the twelve miles back to their ship. I retired and was nearly sick. They returned the next day, still in the thickest fog l've seen in the Firth of Forth. It was a fine achievement on the part of the Oak in getting them through but very late, and they brought their replies. Generally speaking, they would agree to anything.'

The reason for recording the events which occurred at the meeting between Admirals Meurer and Beatty on the Queen Elizabeth is to provide a broader perspective to epochal events of which Maj Ind was a peripheral observer. SM.]

\section{SERVICE IN THE BALTIC 1918-1919}

The Caradoc was on patrol during the period 9-11 November (these patrols usually being of three days' duration) and on 12 November was about to be relieved. Eventually, we sighted our relief, a destroyer leader (HMS Parthon), and the first signal that she conveyed to us was 'Armistice was signed yesterday at 11.00 o'clock'. This message was inevitably greeted with great jubilation throughout the Caradoc, and leave was eagerly anticipated. On the route up the Firth of

\section{The War of Intervention in Russia}

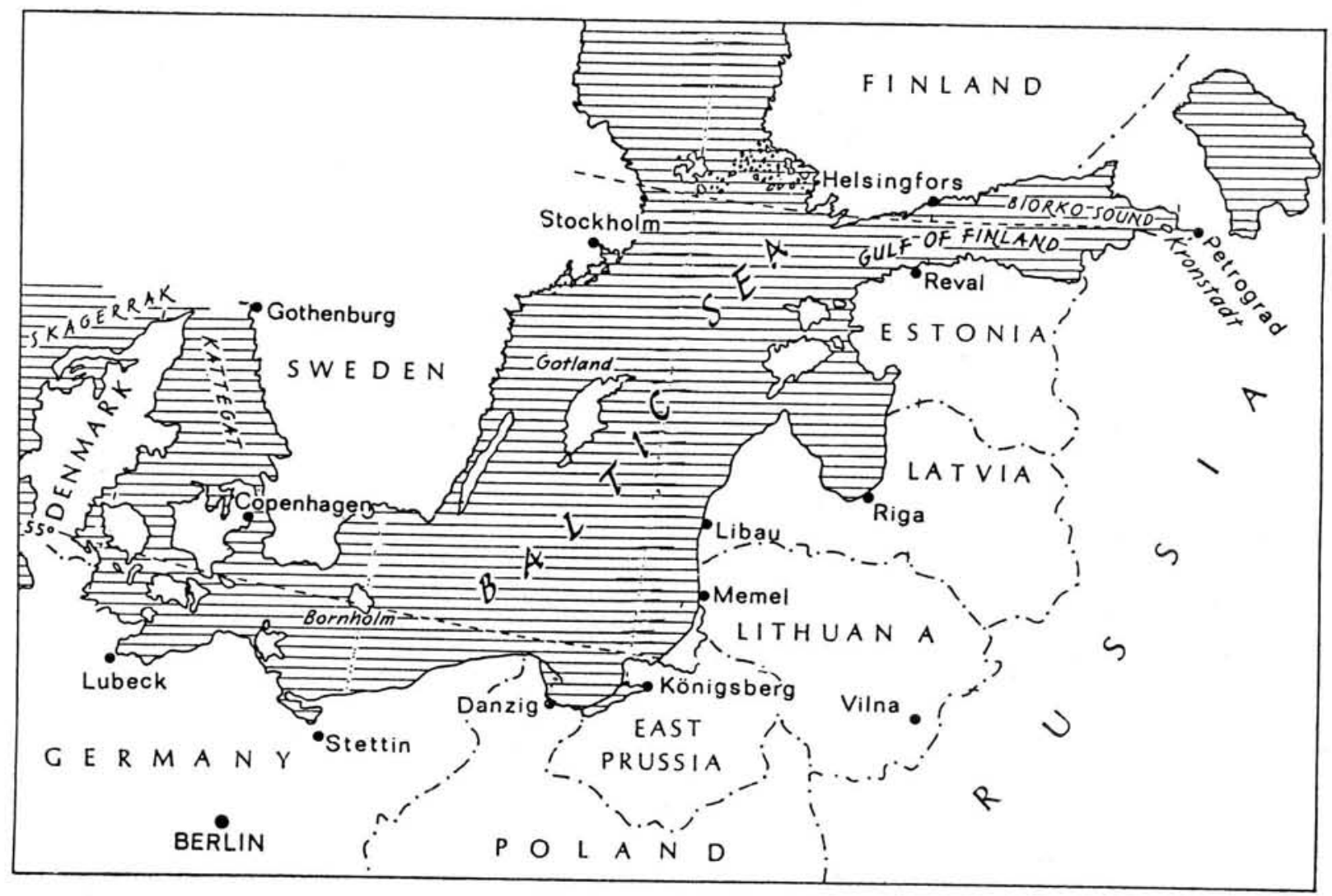


Forth is a place called Inchkeith, where a small signals station was then located. It signalled in semaphore (not possessing radio communication):

'Anchor here, lighters will be sent alongside to re-ammunition, to restore, to rewater, etc and special arrangements will be made for wartime personnel in taking them off.'

This process took approximately $3-4$ days. No leave was granted. On 26 November we were in harbour in Copenhagen, on a goodwill mission. These were familiar waters to the 6 Light Cruiser Squadron, and at one point in the war we had sunk 27 German trawlers in this section, before breakfast. On the second night out from Copenhagen, we anchored in a bay at a place called Libau, on the border of Germany and Russia (in Latvia). Here a passenger boarded the Caradoc and soon after, in the early evening, we resumed our sea voyage. When we were clear of Libau, the Captain addressed the crew on the public address system. He stated:

'Ship' Company: I want you to listen to me carefully. We are here at the request of the monarchist government in Russia to give them assistance against the Bolsheviks, which from now onwards will be known as the Red forces. On board is a Russian pilot, and he has brought with him a certified course which he calls the "thin red line". We will follow that course in accordance with his instructions and guidance and my sealed orders which will be opened at a certain time and date.'

[Maj Ind is referring to a highly complex situation resulting from the independence of the Baltic states at the end of World War I. At the time of the Armistice of November 1918 the Bolshevik forces were firmly in control of Petrograd (formerly St Petersburg, later Leningrad), and of the considerable Russian fleet situated at Kronstadt.

Following the Russian Revolution the Baltic states of Estonia, Latvia and Lithuania declared their independence from Russia, and had been awarded de facto recognition by the Allies. The newly independent government of Finland, under Marshal Mannerheim, was anxious to receive Allied support, in the face of the Bolshevik posturing. The British Government viewed support for the newly independent Baltic states as being synonymous with opposition to the Red Forces then locked in a civil war with the proTsarist faction (popularly known as the 'Whites').
(On 9 December 1917 there occurred a revolt of the Don Cossacks against the newly instituted Communist Government; expropriation of their lands generated the first insurrection. The counter-revolution rapidly spread throughout south Russia and the Ukraine, in which the major campaigns of the Russian Civil War (1918-1921) took place. The area of conflict embraced a wide arc from Odessia in the west, through Kiev, Oren, Voronezh and Tsartzin (later Stalingrad) to Astrakhan and the Volga estuary. On 30 December 1917 a large Japanese force, under General Oatani, landed at Vladivostok. The apparent Japanese intention of annexing the Russian maritime provinces evoked alarm in Washington, London and Paris. During 1918-1919 there occurred an Allied invasion of North Russia.

Small British-French-American expeditionary forces, under British command (Maj Gen Edmund Ironside) occupied Archangel. The ostensible objective was to retrieve Allied supplies and ammunition which the Allied powers had contributed to the Tsarist Government's war effort. In actual fact, the underlying intention was that small forces would invade Russia, striking south and east to link with the Czech Legion in the Urals. (The Czech Legion consisted of approximately 42000 Czech, or Bohemian, former prisoners-of-war from the Austro-Hungarian army, who had transferred their allegiance to the Allied forces in Russia, and had seized control of the Trans-Siberian railway when their proposed re-patriation via Vladivostok was interfered with by the Soviets). This, some Allied theorists argued, would contribute to a united White Russian counter-revolution and thereby destroy the Bolshevik regime. For more than a year of minor but hard fought undeclared war, the Allied forces bickered with the Bolshevik troops along the Vologda River. The Americans were evacuated from northern Russia in August 1919 and from eastern Siberia in April 1920; the remaining Allied troops left in September-October 1919. In the face of the growing strength of the Soviets, the Japanese later evacuated (October 1922).)

These events formed the larger background against which British naval operations in the Baltic - in which Maj Ind was a participant - were enacted. Balfour, the Foreign Secretary, agreed with the Admiralty that 'Bolshevist forces attacking our friends' had to be treated as hostile. ${ }^{10} \mathrm{On}$ 20 November the War Cabinet decided to despatch to the Baltic a cruiser squadron, a destroyer flotilla and a number of minesweepers 
and auxiliary vessels conveying arms; but no troops were to be sent. The force was commanded by Rear Admiral E.S. Alexander-Sinclair. Maj Ind's reminiscences enables us to identify the cruiser squadron as the 6 Light Cruiser Squadron, of which his ship, Caradoc formed a component (and, incidentally, reinforces the value of orally transmitted history, expounded upon in the introduction; in so far as his memoirs enable us to enhance our knowledge of these little known British naval operations in the Baltic during the immediate postWorld War I period). The course which is defined as the 'thin red line' probably refers to the passage between Libau and Reval, the latter situated in the gulf of Finland. Throughout these patrolling activities the mines, liberally sown in the shallow waters of the Baltic by both the Russians and Germans, proved to be a major hazard, as Maj Ind later bears witness. SM.]

On one particular day I had the middle watch (i.e. spanning the time 12:00-04:00), and one other sailor was on duty with me. After I had just completed the watch I suddenly heard two massive explosions. It transpired that the second ship in the line - the Cassandra - had struck a mine. This occurred at the end of November or the beginning of December 1918. [Maj Ind's memory is remarkably accurate in this instance. Stephen Roskill states ${ }^{11}$ that one of Admiral Sinclair's cruisers was sunk by a mine while on passage from Libau to Reval, on 4 December 1918. However, the work Ships of the Royal Navy $^{12}$ states that the Cassandra was sunk on 5 December 1918 (confirming that it was destroyed by a mine in the Baltic). SM.] From apparently nowhere two British destroyers appeared. We were not even aware that we had a destroyer escort. One was the Westminster and the other the Vendetta. The commanders of the respective ships managed to organise the rescue of the vast majority of the crew. There were only some 45 casualties out of a total compliment of 400 . This was highly commendable.

On Boxing Day 1918 we were out on patrol off an island called Hogland, situated midway between Finland and Reval, when we gained our first prizes. We sank two Red destroyers, named Spartak and Amatroil. [Maj Ind is not completely accurate on this point, which is certainly not surprising, in view of the passage of the years which has elapsed since the incident. The destroyer Spartak was in actual fact captured by the British in December 1918 (the date being further testimony to the precision of the narra- tor's memory). Spartak enjoyed a colourful history, having flown under five flags, and an equal number of names. She had been laid down for the Tsarist Navy, under the name of Kapitan $2 R$ Kingsbergen; was re-named the Mikula Maklay by Kerensky's provisional government (March-October 1917) and the Spartak by the Bolsheviks. After being captured by the British she was presented by them to the Estonians, when she was re-named Wambola; being finally sold, in 1933, to Peru, where she was allocated her fifth name, Almirante Villar. The writer has been unable to locate any references to Amatroil, but there is no reason to doubt that Maj Ind is accurate in recalling its destruction. SM.] A considerable time afterwards I received my share of the prize money for these two ships; it amounted to $3 / 9 d$ for one vessel and $4 / 10 d$ for the other.

[After landing arms at Reval to help the Estonians resist the Bolshevik forces, which had approached to within $64 \mathrm{~km}$ of the town, Sinclair moved the greater part of his squadron to Libau. There he encountered a tense situation, as the Germans (who had occupied Latvia in defiance of the Armistice) were preparing to withdraw and the Bolsheviks advancing to Riga, which they captured on 3 January 1919. The British naval force had thus to change their role from supporting the forces of the provisional government to evacuating refugees. By the time that this latter task had been completed they had to withdraw to Copenhagen to avoid being trapped by ice in the harbours of the northern Baltic. SM.]

On more than one occasion I was landed alone on Russian territory, in order to establish ship-toshore communication. I remember one hurried withdrawal from Theodosia following a surprise advance by the Bolsheviks. [Theodosia is a port in the south eastern Crimea. It was one of the ports of the Crimean Peninsula from whence the British fleet evacuated the remnants of Gen Wrangel's White armies, together with any civilians who wished to accompany them. On 28 October 1920 the first Red attacks in the Crimea were delivered in shattering force, in the course of the coldest October in 25 years. Maj Ind is probably referring to this phase of the civil war in citing the attack on Theodosia. SM.] When I returned on board I was informed that it would have created an international incident if I had been caught.

After returning from Baltic waters we received a signal instructing us to proceed to Elsinore Point, off the southern point of Sweden, where a collier 
was aground and we had to effect the vessel's release, which we did. This was the occasion of the shortest signal that I can recall. It read ' $\mathrm{C}$-inC to Caradoc - Well done!' Following our tour of the Baltic, I had the pleasure of visiting Yalta and Constantinople, returning to England through the Dardanelles. [These visits probably occurred after the evacuation of the White forces from the Crimea, referred to above. SM.] We then returned to Portsmouth, and the ship was re-commissioned for a further tour of duty. At that point I held the rank of Boy First Class.

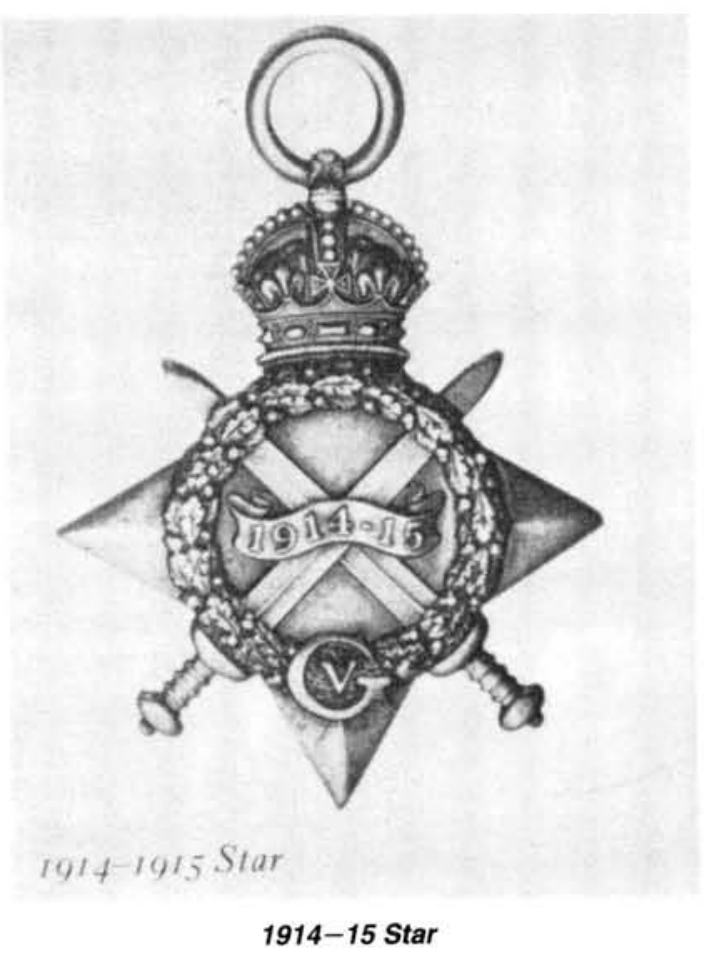

\section{A PROUD MOMENT: I AM CEREMONIALLY PRESENTED WITH THE 1914-15 STAR}

I vividly remember a division (the naval term for a parade) held whilst the ship was at Port Said, one Sunday. I was told to report to the quarterdeck, dressed in No 1 uniform. Upon doing so, I was amazed to see the entire ship's company assembled, the officers lining each side of the ship and the Captain seated behind the table reserved for prayer, in front of which was a carpet. I was lauded for my great patriotism and formally presented with the 1914-15 Star. A fellow rating, who had served with me in the Caradoc was among the first to congratulate me. I recall this incident with particular pleasure. His name was 'Tubby' Luff and, whilst we were serving together, he had reprimanded me on the grounds that I was wearing the ribbons of my father's World War I campaign medals [ie the
1914-15 Star, British War Medal 1914-20 and Allied Victory Medal. SM.] and would be involved in serious trouble as a result. [Maj Ind was probably the youngest recipient of the 1914-15 Star. SM.]

\section{AM ATTACHED TO THE SOUTH AFRICAN NAVAL FORCES}

I was posted to the Wallace, a destroyer leader and thus an elite ship. I interpreted this as a compliment to my ability. I remember that shortly afterwards we embarked upon a goodwill visit to Amsterdam.

I was engaged in one of the destroyer exercises, approximately at the estuary of the Firth, when a signal which was to prove epochal in my future career was received. I was being relieved of duty in the mid-afternoon, when the Coxwain said to me: 'Oh, you're just the character I want to see. I've been asked to put this to you, and its very much in your interest to think about this seriously and say "Yes". The South African Government is forming a new Navy and they have asked the Admiralty for three signalmen, a limited number of Coxwains, a limited number of engineers and a limited number of Stoker Petty Officers. The Captain thinks that it will be most fitting for you, in the light of the progress that you have made in the Navy to date, and your dedication and interest in your work, to give this consideration.' 'Well, I was fuming. I had seen so little of my family since I had joined in 1916. I said, 'No, what about leaving me where I am, or having another posting with the fleet?'. He said: 'Let me repeat again, it is the Captain's wish, and he feels that you are the right man.' Then the Coxwain added the rejoinder, 'For what its worth, I go with the Captain.'

Eventually, I agreed, although hoping that I would not be selected. But, several weeks later, I learnt that I had been so chosen. I was on a three year contract with the South African Navy. At that point in time I was a Leading Signalman. I arrived at the dockyard at Devonport, and came to the dry dock, where I discovered two trawlers. This occurred in mid-1921. The two trawlers were named HMS Eden and HMS Foyle. They had not been used for their normally allotted role of collecting fish for trawlers and rushing the cargo to the fishing ports, but were minesweeping trawlers.

The vessels were coal-burning and their maxi- 
mum speed was some eight knots. Their crews were aghast at the thought of the trawlers travelling to South Africa; 'You'll never get there' they said. I travelled in HMS Eden, commanded by Lt Scott Napier, DSO; the Foyle was commanded by Lt Cdr AE Buckland, DSO, DSC.

[There was, in actual fact, a third ship allocated to the South African Naval Services. This was the Crozier, commanded by Cdr D.E. St M. Delius, $\mathrm{OBE}$. The Crozier had originally been a twinscrew minesweeper of the later Hunt class. The ship had originally been named the Ventnor, and later the Verwood. The Eden and Foyle had also been re-named; originally named Thomas Johns and John Edward respectively. They belonged to a class of Admiralty trawlers which were named from the list of able and ordinary seamen who, according to her muster roll, fought in HMS Victory at the Battle of Trafalgar (1805).

The three ships had been commissioned on 15 November 1921, at Devonport, outside Plymouth. The Union Government's acquisition of the three vessels originated at an Imperial Conference held in London, early in 1921. The South African delegation at the Conference was represented by the Prime Minister, J.C. Smuts; the Minister of Defence, Col Mentz; and the Secretary for Defence, Sir Roland Bourne. The previous arrangement concerning the Union Government's support of South African naval forces had consisted of an annual grant of $£ 85000$ ( 50000 from the Cape and $£ 35000$ from Natal). This was now considered to be obsolete. In the place of this monetary contribution, it was agreed that South Africa would:

(a) Assume the responsibility for the hydrographic survey of South African waters;

(b) Initiate the nucleus of a Permanent Seagoing Naval Force;

(c) Bear the cost of certain development works in the East Dockyard at Simonstown; and

(d) Expand the South African Division of the RNVR in order to provide the men necessary for local defence flotillas and similar services.

To assist the Union Government in implementing these objectives, the British Government agreed to donate to South Africa a survey ship and two minesweepers, from her stock of surplus vessels; the three ships named above were thus selected. SM.]

We left Plymouth at noon on 15 November 1921. and it took us eight days to reach Madeira, arriving there at approximately 06:00. During the first four days of the voyage I was as close to death as I ever want to be, due to the stormy conditions. Drinking water had to be strictly rationed at all times. We stopped at Sierra Leone, to take on coal, drinking water and provisions. We then crossed the equatorial bulge of West Africa - the Bay of Biafra - and adopted a slanting course down to Walvis Bay, a journey which consumed 14 days. We saw no sign of any ship, being well clear of the shipping routes.

Just before reaching Walvis Bay, the stokers began to manifest considerable discontent and unrest, which escalated. The coal taken on at Sierra Leone was inferior, and not suited to the trawlers' boilers. The stokers addressed their protests to the Coxwain, the Captain's right hand man. The Captain gave me a very direct warning, to the following effect:

'I know that you are in a very awkward position, as you live and sleep with these men. But if you get involved with any of this nonesense - which seems to be growing a bit day by day - I shall have no hesitation in shooting you in the same way that I will shoot the others.'

I had no doubt that he would have done so too, his being a determined and resourceful man. (He was minus two fingers, a 'souvenir' from his service in the Allied Expeditionary Force to Russia.) The unrest eventually died down. Scott-Napier smoothed over the problem by embroidering the truth concerning such matters as the time of arrival. He certainly would have had no hesitation in ruthlessly suppressing any mutinous behaviour.

In Walvis Bay we procured a pilot to guide us through the very long approach to the harbour. The seamen began to fish, as we eagerly looked forward to fresh fish and chips, which would have presented such a refreshing change from 'Admiralty ham' (i.e. bully beef). However, it transpired that what we had caught was in fact inedible baby shark. We left Walvis Bay for the final phase of our trip to Simon's Bay, which we reached on 11 January 1922, after 50 days at sea. We received the signal to harbour outside the dockyard, as the dockyard had been closed. There was no special welcome. [The arrival of the three ships did, however, merit a report in the Cape Times, dated 13 January 1922, and, significantly, headed Nucleus of Navy ${ }^{13}$ : 
'His Majesty's Surveying Vessel Crozier, which with the trawlers Eden and Foyle, have been acquired by the Union Government to form the nucleus of the South African Navy, arrived here last night from England, calling en route at Gibraltar, Las Palmas, Sierra Leone, Lagos, St Paul de Loanda and Walfisch Bay. SM.]

After a year or so the names of the ships were changed; Eden being re-named HMSAS Immortelle and Foyle HMSAS Sonneblom. [Crozier was re-named HMSAS Protea. The SANS also consisted of HMS Afrikander, a Royal Naval depot ship. This re-christening of the Crozier, Foyle and Eden was noted in the Army, Navy and Air Force Gazette, dated 2 December 1922. SM.]

I was mainly engaged at a large signals station located at the summit of Table Mountain which had direct communication with the Air Ministry in England.

One incident that I vividly remember was the grounding of the Immortelle. The flotilla had been involved in a good deal of practical training of the RNVR lads from Cape Town, and the time had come to return to Table Bay docks, discharge the local lads and then return to our base at Simonstown. Immortelle and Sonneblom left Saldanha Bay, the former being the senior ship. At approximately 16:00 we passed Jutten Island, and a deep and intense fog had set in. It was quite cold. Whilst steering a course between the island and mainland, I asked my captain if he would like a cup of cocoa, and would certainly receive a reply in the affirmative. My captain was Lt Tim Goddard, an ex-Conway boy. Conway has a long history in the category of training ships, and anyone who could rightly claim to be a 'Conway graduate' was in a way comparable to a product of Oxford or Cambridge. [HMS Conway trained boys for entrance into the British merchant marine. SM.] The three of us (a young sub-lieutenant being with us) had all had a sip of cocoa when we heard two words, 'rocks ahead'. Immortelle came to a grinding halt, amidst the sound of much scraping. We seemed to be wedged in between big rocks on either side of us. We heard a human voice coming from land. He

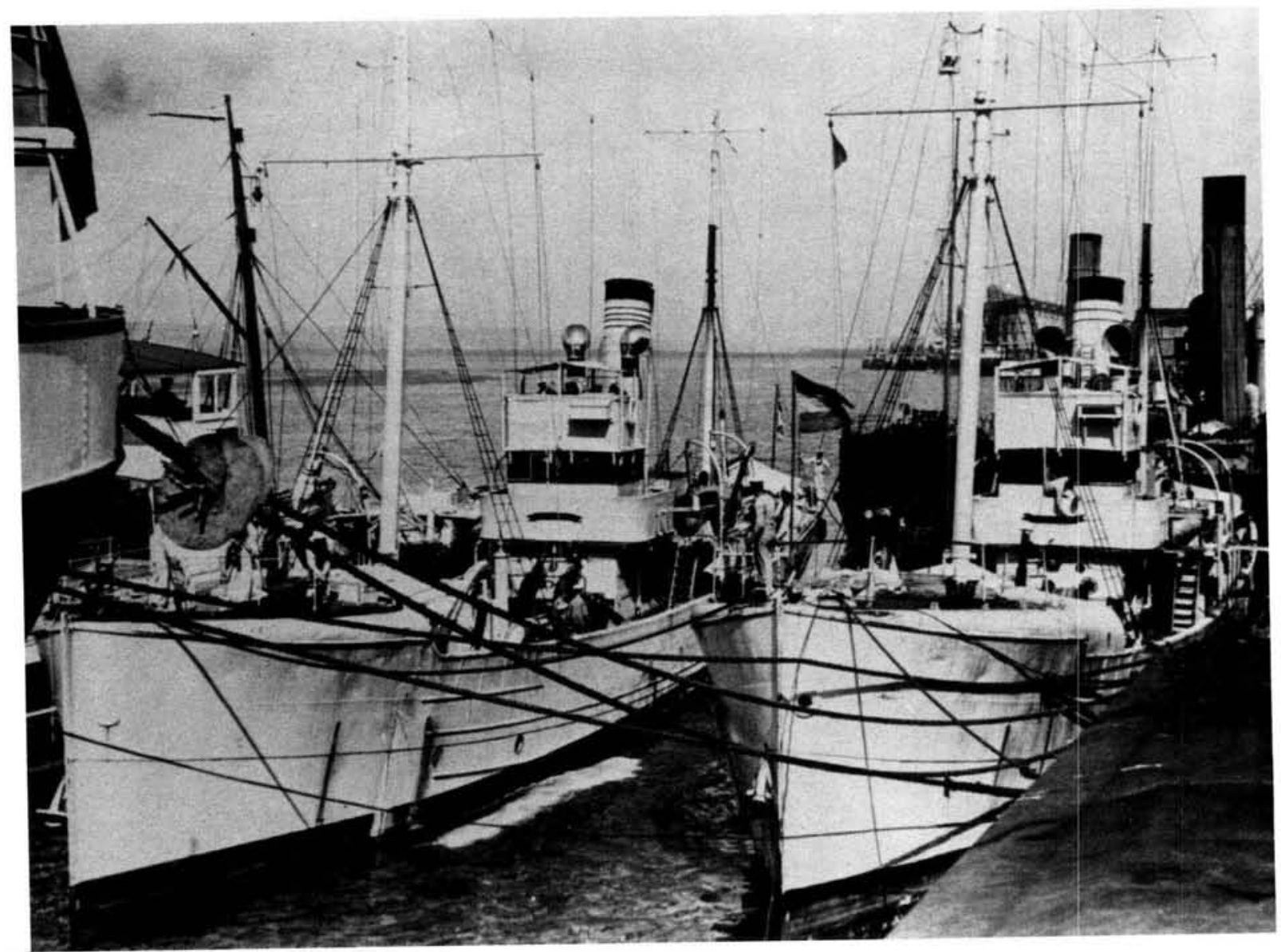

The trawlers Immortelle and Sonneblom.

(With kind acknowledgements to Cdr W.M. Bisset, Staff Officer, Naval Museums.) 
was a Portuguese man named Almeida, and the gist of his introduction to us was:

'If you listen to me and do what I say you have a chance of getting off.'

The position appeared to be so serious that we began to discharge our boys from the Immortelle to Sonneblom by skiff, so that they would be safe. The operation was smoothly carried out, being expedited by the assistance of Sonneblom's skiff. Most of the local lads had a cold boat trip, and in night attire. It was lucky for them that the majority had pyjamas, which is not an accepted part of a sailor's kit. Now it was a case of wire and rope being secured to certain points on the rocks and the head man (Almeida) controlled this aspect of the operations with his own men (apparently coloured), and with the best flow of expletives that even to this day has ever come my way.

According to naval practice, just after a captain has delivered the order to 'abandon ship' it is the signalman's duty to throw the confidential code books overboard, and these books are weighted with lead. The books were, accordingly, placed in the canvas bag, but I refrained from casting them overboard (a fact for which the captain was afterwards very grateful). The operation of pulling free from the rocks consisted of a combination of pulling the ropes in various directions and working the ships' engines very slow astern.

When we were able to proceed under our own steam and make the voyage from Cape Town to Simonstown, our speed was a crawling pace of some three knots. We had only one screw and the propeller had lost a piece of one of its three blades. We were well aware that full speed, or, indeed, any speed in excess of three knots would have been stupid in a trawler which had already had to suffer a voyage of approximately 7000 miles. Our repairs were effected after only a short time in dry dock.

My major role in the SANS was the training of Royal Naval Volunteer Reserve (RNVR) personnel at the four wireless bases situated at Cape Town, Port Elizabeth, East London and Durban. [The origins of the RNVR in South Africa may be traced back to 1885 , when a volunteer corps for the defence of the port of Durban was established, mainly due to the initiative of Mr Harry Escombe. The Natal Naval Volunteers, as the unit was termed, was mobilized in September 1899, and detachments were present at Lady- smith, Colenso and Estcourt, where they served with the British forces, and subsequently throughout the Anglo-Boer War. They were later deployed in the field during the course of the Zulu Rebellion of 1906-1907. In the early months of 1903 an Act of Parliament in Britain instituted a naval corps, based upon part time service in the navy, designated the Royal Naval Volunteer Reserve. In 1905 a corps of naval volunteers was established in Cape Town, designated the 'Cape Colonial Division, Royal Naval Volunteer Reserve.' In terms of the Defence Act of 1912, provision was made for the establishment of a South African Division of the RNVR, into which the Natal and Cape Naval Volunteer Corps were integrated. SM.] Each of these bases was commanded by a Royal Navy Chief Petty Officer; the Cape Town base was sometimes commanded by two Chief Petty Officers. These senior non-commissioned officers were: Douglas Wheeler (Durban); CPO Howell (East London); CPO Fotheringham (Port Elizabeth); and CPOs Pedler Palmer and Williams (Cape Town). I knew every commanding officer personally. I distinctly recall Lt (as he then was) W.B. Collier, who commanded the naval forces in Durban; and, in East London, Lt W. Chambers

I served with the South African Naval Services during the period 1922-1934, when the unit was disbanded. [The South African Naval Services proved to be an early victim of the depression, and resultant policy of extreme austerity. On 30 April 1933 HMS Protea was paid off and returned to the Royal Navy, the crew being discharged. The total strength of the SANS was thenceforth reduced to nine officers and 47 ratings. On 31 March 1934 HMSAS ships Immortelle and Sonneblom were also paid off and handed back to the Royal Navy, their crews being discharged. In practical terms, these measures implied the death of the SANS. Nevertheless, it was retained as an organization, consisting of the following:

(i) A staff officer, SANS, holding the rank of Lt Commander in the Royal Navy, on loan to the Union Government. He was in charge of administration and acted as a naval link between the Commander-in-Chief of naval forces and the South African Government. His Headquarters, located at Simonstown, was staffed by a small civilian staff of six, the senior of whom acted as Paymaster and took charge of such naval stores as were required, including those held in reserve for war commitments. 
(ii) The instructional staff of the RNVR (SA), consisting of two officers and nine senior ratings from the Royal Navy, in addition to four civilian clerks (one at each base). Maj Ind would then have been serving as one of the nine senior ratings of the RNVR instructional staff. Thus, his post would, in all probability, not have been made redundant.

(iii) The Hydrographic Survey Section, consisting of two officers and three ratings.

This organization continued until the outbreak of World War II. SM.]

I initiated all the training in signals and in 1929 was appointed Chief Signals Instructor to the entire South African Army. At that point I was a Yeoman of Signals (the technical equivalent of Petty Officer) and was promoted to Acting Chief Yeoman of Signals (Acting Chief Petty Officer) in recognition of my enormously expanded responsibilities. In 1934 I was allocated additional time to say an official farewell to the bases in Durban, Cape Town, Port Elizabeth and East London, and also to wind up affairs satisfactorily at these bases. I also received a further six months service with the Union Defence Forces.

I was then married and had two children, and was faced with the prospect of being returned to the Royal Navy and probably sent on a tour of duty overseas. But I thought of an alternative, and asked to see the Admiral. I requested a transfer to the military authorities in Pretoria, as a signals instructor. The Admiral supported my application, which was accepted.

\section{ROBERTS HEIGHTS 1934-1940}

My transfer to Roberts Heights, as it was then known, in 1934, involved a drop in rank to Sergeant (vis-a-vis my naval rank of Acting Chief Petty Officer). I was sent to the South African Military College, as a member of the SA Instructional Corps. The College consisted of some 25-30 staff members. The OC of the College was Lt Col D.J. Roux, and the senior instructional staff included Capt H.S. Cillier and Sgt Maj Louw. I was promoted to Staff Sergeant. Although the majority of instructors were Afrikaans-speaking, the language of technical instruction continued to be in English for many years. I took over all the lecturing duties in English. With regard to my proficiency test, I had to set my own exam, which I then wrote. I was at the college for one year. On 27 October 1934 । was awarded the Long Service and Good Conduct Medal (Permanent Forces of the Empire Beyond the Seas Long Service and Good Conduct Medal)* at a medal parade at which the senior officer was Col George Brink (then OC of Cape Command); his ADC was Capt - later Air Vice Marshal Sir - Charles Warburton Meredith. The date remains clearly impressed on my memory because, when I arrived home that evening, I was greeted by the midwife, who told me that she had delivered my son, Colin.

I saw little future for myself at the College, or as a member of the Instructional Corps, as I realized that Afrikaans would play an increasing role in service life. My feeling of unease at this prospect was heightened by the RSM victimizing me at a mass parade, for calling out '19' in English, instead of Afrikaans. I reminded him in good naval language that it was not a condition of my contract to deliver instruction in both languages. I also stated that I had made good progress in studying Afrikaans, but from that day forth I ceased to be interested in the language.

One day I was sent for by the Adjutant. I told him that I had been involved - to a small extent - in catering on board ship. He offered me the post of being in charge of catering for the officers' mess at Roberts Heights, and I accepted. I was to receive $£ 3,00$ per month as an honorarium. Serving in this role until the beginning of 1940 , I proved to be a huge success in this job. The majority of officers at Roberts Heights at that time were pilots, in addition to a few Special Service Battalion officers and a padre (the latter of whom was the main instigator of the rowdy nights in the mess.) [At this time the SA Military College, Pretoria, served as the 'clearing office', so to speak, of commissioned airmen, who were drafted to various posts as vacancies occurred in the SAAF. The first 10 SAAF-trained air cadets had graduated in 1927, when the SAAF flying badge (wings) had been awarded for the first time. In December 1930 the first six 'amphigarious' officers had been commissioned as airmen. The term 'amphigarious' derives from the Greek, meaning 'earth-and-air-together-in-one'; as economic depression and resultant austerity rendered it necessary for cadets to qualify as both army and air force officers, to gain entry into the Permanent Force. SM.] I was on very

\footnotetext{
* Now obsolete; superseded by: the Medal for Long Service and Good Conduct (Military) (1939); the Union Medal (1952); Permanent Force Good Service Medal (1961); and the extant South African Defence Force Good Service Medal (1975). SM.
} 
good terms with Lt Col (later Maj Gen) H.J. Martin, and catered to well over 100 officers in the mess. This close rapport with the Air Force during that Service's early history was to have a decided effect upon my future career.

\section{THE SOUTH AFRICAN AIR FORCE: A PIONEER IN SIGNALS TRAINING FOR THE SECOND TIME}

One day, early in 1940, two officers visited me. They were a Lieutenant le Measurier and a Major Pope. Pope said, 'We have a strange request to make to you, and we do hope that you'll agree to it. We have no signals division whatsoever, in the SAAF; won't you think about starting it off.' [At this point in time, there were virtually no Permanent Force instructors in the SAAF. A number of short-lived training schools had been established, but the preponderant burden of training fell upon the shoulders of light aeroplane clubs and private companies; with the necessary corollary that instructors and ground staffs were civilians. SM.]

I accepted their offer. Once again, I had that adventurous feeling, and felt that I could vitally contribute to the SAAF by developing their signals section. But I insisted on promotion, and was told that I would be promoted to the rank of Sergeant Major immediately, to be commissioned immediately afterwards as a 1st Lieutenant. This indeed proved to be the case. I was a Sergeant Major for a matter of only months before being commissioned.

In 1940 I started the Signals Operating School in Durban (at Shellparade Camp). There, virtually all my operating instructors were ex-post office personnel. It was a disused military camp, which also housed Natal Command. I was very happy at Snellparade, mainly because the ex-post office personnel knew their morse code so well; in some cases better than I did. I remained at Snellparade for some six to nine months, before being transferred to 64 Air School (Signals and Wireless) in mid-1941. This was located at Tempe, Bloemfontein, and was commanded by Lt Col F.C. Elliot-Wilson. I suggested that I should serve on the Signals Board at Swartkops air base. The Board set all the syllabi for the examinations at the different air schools. I found myself on the train for Swartkops within the week. According to the different type of school at which the pilots were being trained, so one had a different standard of signals. The most junior were the elementary flying schools, these being seven in number: Nos 1 and 2 (at Baragwanath and Randfontein respectively); No 3 (Wonderboom); No 4 (Benoni); No 5 (in the Orange Free State); No 6 (Potchefstroom); and No 7 (Kroonstadt). The service flying schools were senior in the level of training, and these were: No 21 (Kimberley); No 22 (Vereeniging); No 23 (Waterkloof); No 24 (Nigel); No 25 (Standerton); No 26 (Pietersburg); No 27 (Bloemspruit).

My responsibilities were enormously expanded by the institution of the Empire Flying Training Scheme. [Maj Ind is here referring to the Joint Air Training Scheme. The genesis of this programme dated from December 1939, when Gen Smuts offered facilities in the Union for the training of South African and RAF airmen in a joint scheme. At that point in time South Africa's contribution to the project was simply unlimited space and good flying weather. However, after five months had elapsed the Royal Air Force despatched an air mission to the Union, led by Air Marshal Sir Robert Brooke-Popham, which arrived in late April 1940. South Africa was then in a position to provide instructors, airfields and materials to build the airfields, whilst Great Britain was to supply aircraft and artisans. It took a full 18 months for Lt Col H.J. Martin to fulfil his brief of surveying the country for suitable sites, bombing and gunnery ranges. The Joint Air Training Scheme, thus initiated, was to exercise far reaching effects upon the Allied air forces' war effort. The programme trained 33347 pilots, observers, navigators, bomb-aimers, air-gunners and wireless operators. Of these, 20800 were allocated to the RAF; 12221 to the SAAF; and 326 to Allied air forces. The earliest air schools were situated at Baragwanath, Randfontein, Kimberley, East London, Oudtshoorn, Cape Town and Port Elizabeth. By December 1941, 29 air schools had been established under the scheme, training 9522 airmen. SM.] The scheme involved the importation of a large number of RAF personnel, including signals specialists. The school at Standerton, for example, was staffed entirely by RAF signals personnel.

I still vividly recally the very first class of pupil pilots whom I instructed. The class was eight in number and I especially remember a 2 Lt (later Commandant General) SA Melville.

In 1943 I left for the United Kingdom, on an information gathering exercise, in the course of which I visited every air school in Great Britain. I 
remained in the United Kingdom for one year. Memories which remain of that visit include those of civilians sleeping in tube stations and the frequent appearance, outside bombed buildings, of notices declaring "business as usual'. Upon my return I spent some three months at Defence Headquarters recording my studies of RAF signals operations. I was then posted to 64 Air School once again, which expanded very considerably during the war. In 1943 I had been promoted to Captain, with the rank of acting Major during my tour of Great Britain. I continued my service at the School after the war, becoming its OC in 1947, with the rank of Major. I retired from the Permanent Force in August 1955.

In looking back upon my long and extremely varied military career, I can best summarize it by expressing thanks to God for my adventurous spirit.

\section{Author's epilogue}

Having had the privilege of being the receptacle or medium of Maj Ind's memoirs, the dominant impression conveyed by him is one of patient fortitude and extreme dedication to service life, despite its fluctuations in tempo (especially with regard to the contrast between peace-time and war) and frustration of aspirations and ambitions. Such resilience implies a quiet forebearance which was, possibly, concealed by a somewhat pedestrian method of delivery, which nevertheless was characterized by extreme precision in the recollection of episodes long distanced from the reader in time. It is oft commented that the strength of any institution (including, of course, military organizations) resides in its weakest link; in other words they are overwhelmingly dependent upon the moral fibre of the rank and file. Maj Ind was a fine exemplar of the characteristic fibre of the rank and file, within both the Royal Navy and the Union Defence Forces, and the projection of both his personality and service thus merits the detailed treatment which it has received in this article.

Maj Ind's autobiography is, perhaps, an important pointer to the fact that the outcome of historical events is heavily dependent upon the characters of those anonymous individuals whose endurance and suffering are frequently by-passed by historians. It is, however, difficult to explain the successful British defiance of the blitz on London in 1940-1941, or the incredible fortitude with which the British soldier faced four years of appalling trench warfare in the Great War (Maj Ind's memoirs bearing testimony to the latter phenomena) without taking into consideration the fibre of such often unnamed and unremembered individuals. This is a sphere which, perhaps, the military historian has too long overlooked. SM.

${ }^{\star}$ Dr S. Monick is attached to the S.A. National Museum of Military History.

\section{Bibliography: sources referred to in the text}

1 Liddell, Peter H. The sailor's war 1914-18. Poole (Dorset): Blandford Press, 1985, p 25.

2 Quoted by Callwell, C.E. The Dardanelles. London: Constable, 1919, pp 68-69. (Campaigns and their lessons).

3 Wykes, A. First landings in Gallipoli in History of the First World War. London: Purnell, Vol 2, p 771.

4 James, Robert Rhodes. Gallipoli. London: B.T. Batsford, 1965, p. 221

5 Wright, Richard. Gallipoli: the second stage, ibid itern 3 above, Vol 3, p 911.

6 Ibid item 4 above, p 221

7 Ibid item 1 above, pp 24-25.

8 Chalmers, W.S. The life and letters of David Beatty Admiral of the Fleet. London: Hodder \& Stoughton, 1951, pp 342-343.

9 Cited ibid item 8 above, pp 344-345.

10 Quoted by Roskill, Stephen. Naval policy between the wars. London: Collins, 1968, p 144 .

11 Ibid item 10 above, $p 145$.

12 Colledge, J.J. Ships of the Royal Navy: an historical index. Vol 1: Major ships. Newton Abbot: David \& Charles, 1969, p 109.

13 Goosen, J.C. (Comp). South Africa's navy: the first fifty years. Cape Town: W.J. Flesch, 1973, p 11

Note: Photographs furnished by the author. 